\title{
VIDA Y SOCIEDAD EN LA ESPAÑA DEL SIGLO XVII A TRAVÉS DEL «COLOQUIO DE LOS PERROS* DE CERVANTES
}

Es corriente en la época que vivimos ver al historiador apoyarse en las fuentes documentales de una manera casi exclusiva para desvelar el pasado histórico. Admitir que las fuentes principales para la investigación histórica son dichos fondos documentales que conservan los archivos, no exluye, en absoluto, el carácter de fuente para la historia de la obra literaria. Si el historiador menosprecia esta fuente estará negando una parte del pasado que ni legítima ni cientificamente puede rechazar.

Aceptando las evidentes limitaciones que presenta la Literatura como fuente para la Historia, hemos optado por ella porque, debidamente contrastados los datos que la obra literaria nos ofrece, es suceptible de aportar noticias y puntos de vista que en modo alguno se hallarán en documentos que se definen por su marcado carácter oficial. Tratándose además del «Siglo de Oro», crítico en muchos aspectos y sujeto a continuas revisiones desde hace unos veinticinco años ', la obra literaria en general, y la novela cervantina en particular, se erigen en testimonio insustituible para el conocimiento y la caracterización de la época, para pulsar, como diría Maravall, «la conciencia coetánea de crisis y la conflictividad social».

El siglo XVII posee una profundidad insuficientemente advertida, al menos hasta hace poco, que llevó a considerarlo como una etapa deprimida, sin apreciar sus claros perfiles críticos, entre

${ }^{1}$ P. Fernández albaladejo, "Veinticinco años de debate sobre la crisis del siglo XVIn, T. Aston (ed.), Crisis en Europa. 1560-1660. Madrid, 1983, pp. 368386. 
dos épocas de esplendor. En el fondo se trataba de una burda simplificación, carente de matices espacio-temporales, que siempre contrastó, y así se admitió, con la existencia de una producción artística y literaria de singulares proporción y calidad (el no en vano llamado "Siglo de Orow), sin percibir su alto contenido de denuncia, de cambio en potencia, de época bisagra, preparatoria de las reformas que empezaron a ser una realidad en el siglo XVIII

Todo lo anterior es especialmente rastreable en los aspectos elegidos para nuestro estudio: la historia social y la historia de las mentalidades. Ambas necesitan un tiempo más largo que la historia política para sus cambios intrínsecos, lo que no hace más que reforzar el interés que poseen en sí mismas esas dos facetas. Reafirmamos, pues, la radical importancia del siglo XVII para los estudios de historia de la sociedad y de la mentalidad, incluso más que para la historia política, al menos en el caso de España.

La relación SOCIEDAD-LITERATURA no es unívoca. Se trata de una interrelación en la que las circunstancias históricas influyen en la literatura y ésta a su vez incide en la sociedad. Así es como puede hablarse de una "cultura dirigida".

El uso de la literatura como fuente para la historia no es novedad. Sin embargo, su tratamiento ha soslayado a menudo su riqueza en cuanto a aportación de datos, en aras de una aceptación o rechazo de la obra literaria en virtud de su estilo o, incluso, ha derivado en polémicas, como la que enfrentó a Américo Castro con Claudio Sánchez Albornoz, que antes que conducir a la aportación de datos históricos contrastables, ha llevado a una discusión historiográfico-literaria de interpretación, prácticamente estéril.

\section{El BARROCO. ESTADO DE LA CUESTIÓN}

En un breve estado de la cuestión en torno al concepto de «barroco», hay que señalar la evolución que sufre el término desde su uso como un simple adjetivo a la consideración como concepto de época.

Hasta finales del siglo XVIII el término barroco responde a distintas acepciones: perla en forma irregular (barrueco o berrueco), expresión correspondiente a una fórmula silogística procedente de la Escolástica (barroco) o término jurídico, de origen toscano, que designa una forma de contrato usurario o sea de engaño (barroco $)^{2}$. Las connotaciones de estos tres significados, en lo que

${ }^{2}$ E. ORozco Dîz, Introducción al Barroco. Granada, 1988, vol. I, pp. 28-29. 
se refiere a irregularidad, artificiosidad y engaño, indican ya una actitud inicial peyorativa hacia todo aquello que se calificase con el adjetivo barroco.

Será en el siglo XIX cuando el término adquiera una significación más amplia: el barroco como estilo artístico. Inevitablemente su primera utilización, apoyada en la carga conceptual aludida anteriormente, se reviste de un matiz despectivo y decadente con respecto a las manifestaciones artísticas de la época anterior. Esta es la línea de autores como J. Burckhardt, entre otros muchos.

De la consideración estilística del término deriva otra interpretación que contempla «lo barroco» como una fórmula artística recurrente, que aparece con intermitencia, coincidiendo con la etapa decadente de los distintos estilos. Esta es la interpretación de Nietzsche (1878) y es una línea que ha continuado en nuestro siglo, aplicada no sólo al terreno del arte sino también al de la literatura (d'Ors).

Hasta las últimas décadas del siglo XIX el estilo barroco careció de un análisis en profundidad. Esta tarea fue la tarea que desarrollaron Gurlitt (18770 y H. Wölfflin (1888) en el campo artístico, concretamente en la arquitectura. Este último revalorizó el término y algo más tarde comenzó a aplicarlo también a la Literatura y a la Música. Al generalizarse el interés por este tema, hubo que analizar su trasfondo ideológico. Los autores alemanes fueron pioneros en este campo, destacando R. Wellek y Hatzfeld, quien otorgó un protagonismo, quizás excesivo, a los países del área mediterránea-católica.

El Barroco había encontrado un lugar propio en la Historia de la Cultura, a la vez que su horizonte se iba ensanchando de la mano de autores como Hauser. Un paso decisivo se produjo cuando a los factores estilísticos (ya sin carga peyorativa) e ideológicos se unió la relación con el contexto histórico. Se fragua así la consideración del barroco como un concepto de época, que ya señaló Orozco y que desarrolló ampliamente Maravall.

La relación con el contexto histórico conduce inevitablemente a la fijación del marco cronológico del barroco, pero también a la consideración de la coordenada espacial: «Si elementos culturales repitiéndose -escribe Maravall-, aparecen una y otra vez en lugares distintos, consideramos, sin embargo, que tan sólo articulados en un área geográfica -y en un tiempo dado- forman una estructura histórica. Eso que hemos llamado "concepto de época" abarca, pues, los dos aspectos" ${ }^{3}$.

3 J. A. MARAvall, La cultura del Barroco. Barcelona, 1980 (2.* ed.), p. 34. 


\section{CARACTERIZACIÓN DEL BARROCO}

Si la crítica, como hemos visto al diseñar brevemente el estado de la cuestión, se dirigió en dos sentidos: lo puramente externo y formal y lo interno y conceptual o ideológico, fue precisamente porque algo esencial del estilo se explicaba desde los dos supuestos enfoques. Pero lo cierto es que no nos basta con ellos. Es lo estilístico y lo ideológico, pero enraizados en una situación histórica espacio-temporal concreta lo que nos interesa del barroco. Así, estilísticamente, los rasgos del barroco se encuentran, en su mayor parte, presentes en la obra cervantina, y concretamente en el «Coloquio de los perros".

El barroco es una época sensorial, que busca impresionar al hombre a través de la vía más asequible: los sentidos. En la literatura barroca, la redacción alcanza elevadas cotas de viveza y a la vez de verismo. La exteriorización es una característica inseparable de lo barroco. Sin embargo, el barroco no se queda en la forma. Esta es un medio, pero en absoluto un fin. La sensibilidad barroca va - afirma Orozco- «de lo aparente a lo profundor.

Ya el mismo Wölfflin percibió lo suficiente del formalismo en la consideración del fenómeno barroco, señalando - según recordaba oportunamente Lafuente Ferrari- cómo ken las formas artísticas debemos ver símbolos materiales de lo que el hombre quisiera ser, expresiones aproximadas de los sentimientos que al hombre le parecen en cada momenton ${ }^{4}$. Wellek también insiste en la necesidad de abandonar esos intentos de definir el barroco en términos puramente estilísticos: «hay que reconocer que los artificios estilísticos pueden aparecer en casi todas las épocas. Su presencia es sólo importante si ésta puede ser considerada como síntoma de un estado espiritual específico, si manifiesta un alma barroca" ${ }^{5}$. El alma barroca no es otra cosa que una peculiar "forma mentis», es decir, una concepción determinada del mundo.

Para impresionar los sentidos, nada mejor que el contraste, la extremosidad. Los autores del Barroco utilizan abundantemente la antítesis, que en la literatura equivale al claroscuro en la pintura. Tanto para la crítica como para el aleccionamiento se recurre a la antítesis y los principios y valores que se pregonan resaltan por contraste.

Los contrastes barrocos permiten atisbar una actitud de fondo: el pesismismo. "Para el Barroco español - señala Spitzer- no hay

4 Vid. en Orozco Dfaz, op. cit., vol. I, p. 35.

5 Ibidem, vol. I, p. 36. 
más que un breve paso de lo rosa a lo negro, de la carne a la muerte. Si el hecho espiritual se aparece siempre encarnado y la carne llama siempre a lo espiritual, ese dualismo siempre presente explica por qué el tema barroco por excelencia es el desengaño", el sueño opuesto a la vida, la máscara opuesta a la verdad y la grandeza temporal opuesta a la caducidad, como muy bien matiza Orozco ${ }^{6}$. Lejos de caer en la pasividad, el desengaño se manifiesta de una forma combativa: "la denuncia de la hipocresía y la falsificación que tenían atenazada y corrompida la vida del país»" ?.

Pesimismo y desengaño evidencian una sociedad en crisis. «El hombre adquiere conciencia comparativa de esas fases de crisis. Hay un cambio en virtud del cual ese hombre con conciencia de crisis nos hace ver que ha venido a ser otra su actitud ante el acontecer que presencia, y que frente a la marcha adversa o favorable de las cosas no se reduce a una actitud pasiva, sino que postula una intervención" ${ }^{8}$.

Una sociedad en crisis es, por definición, una sociedad en movimiento, otro rasgo característico de la época barroca, muy distante del estatismo y la mesura del Renacimiento. Precisamente en ella, como bien señala Maravall, se manifiesta "el espectacular y problemático desajuste de una sociedad en cuyo interior se han desarrollado fuerzas que la impulsan a cambiar y pugnan con otras más poderosas cuyo objetivo es la conservación" ".

Dichas tensiones se manifiestan claramente en la técnica literaria: violencia en la narración, movimiento, superposición de agudas pinceladas, sucesión atropellada de episodios, como queda de manifiesto en el "Coloquio de los perros". Para Maravall, "siempre que se llega a una situación de conflicto entre las energías del individuo y el ámbito en que éste ha de insertarse, se produce una cultura gesticulante, de dramática expresión" ${ }^{10}$.

Los recursos estilísticos mencionados, por sí solos o aún en conjunto, pueden presentarse en distintos momentos históricos. Lo peculiar del barroco, concretamente del español, consiste en que tales recursos responden a un orden de valores establecido y ampliamente aceptado. Dichos valores, algunos de los cuales se analizarán más adelante, se articulan en torno a dos grandes principios: el ideal católico y la defensa de la monarquía, princi-

6 Ibidem, vol. I, p. 40.

7 J. L. AlboRG, Historia de la literatura española. Época barroca Madrid, 1970, pp. 16-17 (Introducción).

8 Maravall, op. cit., p. 58.

9 Ibidem, p. 69.

10 Ibidem, p. 91. 
pios cuyos objetivos en modo alguno se contraponen, sino que confluyen.

Nuestra tesis puede definirse, en fin, como integradora, puesto que quiere ver en el Barroco, en primer lugar, una continuidad del Renacimiento, y, en segundo lugar, porque intenta evitar desde todos los puntos de vista la reducción que está implícita en dicha época: el hombre no es sólo cálculo, medida, razón, sino que es, como también quiere el Barroco, pasiones, sentimientos, etc..., y todo en continuo movimiento, oscilación que pone de manifiesto el hecho de que el hombre no es sólo triunfo, sino también derrota.

\section{MARCO CRONOLÓGICO}

Al iniciar nuestro trabajo sobre las Novelas Ejemplares de Cervantes, concretamente el "Coloquio de los perros", hemos de plantearnos el tema cronológico. El problema de la periodización y de la adscripción automática a una etapa determinada sigue todavía abierto: no es posible acomodar la literatura a la noción de siglo y mucho menos la obra de Cervantes, escrita a caballo entre dos centurias, por lo que esto conllevaría de convencional.

Decir que el Barroco comienza en una fecha determinada es tanto como afirmar que no tiene conexión alguna con el Renacimiento " . Ya se ha indicado que nuestra visión del Barroco pretende ser enriquecedora, ya que contempla al hombre en todos los aspectos de su ser, no sólo racionales, sino también sentimentales y anímicos. Por eso, una ruptura con el Renacimiento no existe. Aún más, bajo este punto de vista, el Barroco completa la visión del hombre que formuló el Renacimiento; el Barroco muestra en sus creaciones una voluntad de síntesis. En este aspecto, no compartido por Wölfflin, es la continuidad del arte clásico del Renacimiento y no su antítesis. "La unidad en el arte del Renacimiento - afirma Hauser- era simplemente una especie de coherencia lógica y la totalidad de sus representaciones era nada más que un agregado o una suma de pormenores, en la que todavía se podían reconocer los distintos componentes. Esta relativa autonomía de las partes desaparece en el Arte Barroco»" ${ }^{12}$.

11 "Cervantes realiza la síntesis genial de ambos períodos, pero no faltan quienes le asignan con exclusividad los caracteres de uno solo de ellos. Pfandl, por ejemplo, afirma que Cervantes no era "nada barroco", mientras que Hatzfeld lo estudia de lleno como a tal» (ALBORG, op. cit., p. 11). El mismo autor define al Barroco, no como reacción, sino como "crecimiento y plenitud de una semilla sembrada y madurada durante todo el siglo precedentew (ibidem, p. 12).

12 Orozco DiAz, op. cit., vol. I. 
Admitimos que en el siglo XVII se produce la plenitud del Barroco, pero fijar con precisión el proceso de transformación que hunde sus raíces en el Renacimiento y que concluye con la reacción neoclásica del siglo XVIII es tarea difícil, aunque hay que reconocer que los primeros atisbos de este devenir se observan en los años centrales del siglo XVI y sus últimos coletazos son rastreables bien avanzado ya el siglo XVIII.

En el ámbito literario, la novela picaresca se muestra como uno de los más logrados productos del Barroco y la cronología de las obras típicas del género corresponde al siglo XVII, pero no es menos cierto que el precedente más claro, el «Lazarillo de Tormes" (1554), es del siglo anterior, aunque su formulación definitiva no cristalice hasta que Mateo Alemán redacte su «Guzmán de Alfarache" (1598).

Las Novelas Ejemplares, algunas de ellas con un marcado carácter picaresco ${ }^{13}$, se publicaron hacia $1612, \mathrm{y}$, por tanto, su redacción es anterior. Así, a título de ejemplo, el tiempo histórico en que transcurre la ficción del "Coloquio de los perros" ha de situarse en los alrededores del año $1590{ }^{14}$.

${ }^{13}$ El carácter picaresco de las Novelas Ejemplares ha sido ampliamente debatido y ya Menéndez Pelayo señaló la diferencia entre el género picaresco y las novelas cervantinas. Autores como Fonger de Haan o Chandler se lamentan de que Cervantes no hubiese cultivado este género. Para A. CASTRO, el pícaro cervantino presenta un sello peculiar; se trata de "un objeto en manos de Cervantes, subordinado a su compleja visión del mundow. Valbuena Prat reconoce también esa peculiaridad, señalando que Berganza, el protagonista del "Coloquio de los perros", es «un auténtico pícaro en cuanto narra sus aventuras con sus diversos amos pero, a diferencia de la fatalista pasividad de los hombres en otras novelas, su picardía va tinta en sed de justician (vid. en A. Valbuena y Prat, estudio preliminar de su edición de La novela picaresca española, Madrid, 1962, p. 46). Casalduero estima que Cervantes "roza» el género picaresco, pues frente al acentuamiento de mal que supone este género, la novela cervantina se recrea en el goce de la virtud (J. Casalduero, Sentido y forma de las Novelas Ejemplares, Madrid, 1969, pp. 44 47). Para Bataillon, el "Coloquio" debe incluirse en la picaresca con mayor facilidad incluso que "Rinconete y Cortadillo», porque en él «Berganza cuenta su propia vida a Cipión" (M. Bataillon, Novedad y fecundidad del "Lazarillo de Tormes", Madrid, 1973, p. 103). Rodríguez-Luis reconoce la compleja composición del "Coloquio», destacando tres elementos: la historia de Berganza, la intervención crítica de Cipión y la proyección picaresca. En última instancia el esqueleto de la obra lo constituyen "las aventuras de un criado andariego (en figura de perro)" (J. RoDRíguEz-LUIS, Novedad y ejemplo de las Novelas de Cervantes, Madrid, 1980, p. 37).

${ }_{14}$ Las páginas a las que remiten las citas textuales pertenecientes al "Coloquio de los perros" en el presente trabajo corresponden a la edición de MIGUEL DE Cervantes SaAvedra, Novelas Ejemplares (ed. de Harry Sieber). Madrid, Ed. Cátedra, 1982 (4.* ed.), vol. II, pp. 229-359. Concretamente en las pp. 328-329 de esta edición se encuentra una referencia histórica que alude al Asistente de Sevilla, el licenciado Sarmiento de Valladares, que lo fue entre febrero de 1589 y enero de 1590. 


\section{LA SOCIEDAD DEL «COLOQUIO"}

Hasta bien entrado el siglo XX no cabe duda de que la Historia que se había escrito era historia eminentemente política. La tradición historiográfica en este campo y la aplicación de metodologías cada vez más rigurosas permitían el desenvolvimiento del historiador entre las fuentes con cierta seguridad. Este tipo de historia, que alcanzó cotas brillantes a finales del siglo XIX y principios del $\mathrm{XX}$, sin embargo ofrecía un panorama incompleto de la historia de la humanidad. De ahí el interés, cada vez más creciente desde la década de los treinta, por otras parcelas como la historia económica y la historia social.

Para la historia de la sociedad, aspecto que ahora nos interesa, se presenta un primer inconveniente relativo a las fuentes. No se encuentran fuentes precisas que la abarquen en su totalidad. Los archivos nos ofrecen pleitos de hidalguía $u$ ordenanzas de oficios; los tratadistas aportan teorías que argumentan con todo lujo de apoyaturas en voluminosos tratados. Estas fuentes, sin embargo, van poco más allá de la descripción y caracterización de las bases que ordenan el sistema social. Pero se les escapa la viveza y frescura del acontecer cotidiano. Son raros los documentos de archivo que se ocupan, además de los principios del sistema o de los intereses de clase, de los comportamientos que éstos determinan y aquéllos sancionan. En cualquier caso, los estudios de historia social pueden sustentarse en fuentes diversas.

En este sentido la Literatura y el Arte pueden erigirse en fuentes imprescindibles. La ficción literaria nace de la realidad existente e incluso puede influir en ella. La Literatura es, pues, un testimonio, tamizado claro está por el carácter y el estilo de cada autor, directo para la historia social. Conscientes de la limitación que la obra literaria plantea en el uso como fuente histórica, que apunta al eterno problema de subjetividad-objetividad, creemos ver en Cervantes, además del sello de un escritor genial, la cualidad de un observador crítico de cuanto ocurre a su alrededor.

La utilidad de la obra literaria para la historia social se acentúa en aquellas que se inscriben en una línea marcadamente realista, como ocurre con el "Coloquio de los perros", obra de talante picaresco, aun cuando falten en ella algunas de las notas características de este género ${ }^{15}$. Además, el "Coloquio» compendia

15 John Jay Allen ha sintetizado las características esenciales de la picaresca en las siguientes: narración autobiográfica del pícaro que sirve a distintos amos, sátira de diversos elementos de la sociedad desde la perspectiva del pícaro, acción restringida al nivel moral y social más bajo y a una extensión geográfica reducida, énfasis en las necesidades más elementales como el hambre y de- 
en cierto modo, a base de episodios cortos, la riqueza de episodios, personajes y escenarios presentes en las restantes Novelas Ejemplares ${ }^{16}$. La utilidad para nuestro estudio se acentúa al reflejar la vida y situaciones de personajes pertenecientes, prácticamente en su totalidad, al estado llano, ese macroestamento que siempre se define por exclusión y cuya realidad es tan difícil de conocer a través de las fuentes documentales convencionales.

A través de esta novela pretendemos caracterizar la sociedad del Siglo de Oro, barroca no sólo desde la base de los principios que la informan y la clarificación que determinan, sino también de las connotaciones inherentes a cada categoría social y el comportamiento cotidiano que de ellas se desprende.

La Literatura nos sirve efectivamente para comprobar una vez más la crisis mental del hombre del siglo XVII, crisis que en el terreno de la nobleza basculaba entre dos polos: la concepción de una nobleza poseída unívocamente por nacimiento, capaz de las mayores virtudes, pero también de grandes indignidades, y por otra parte el concepto de nobleza por mérito, cada vez más difundido en el siglo XVII. En opinión de Domínguez Ortiz comienza a ser una realidad en el siglo XVII la contraposición del mérito personal y la nobleza heredada. No fue sólo por el predominio del humanismo, sino también por la creciente influencia de la burguesía, "que soportaba mal que hubiese una prerrogativa que no pudiese conquistar con su capacidad y su dinero" ${ }^{17}$. Sin embargo, de momento sólo se atisba este fenómeno; habrá que esperar al siglo XVIII para hallar una cierta subversión de valores.

\section{PERSONAJES PRINCIPALES}

Entre la variedad de personajes que desfilan por las páginas del "Coloquio" deben destacarse algunos, que por su relevancia pueden considerarse como protagonistas. Dejando aparte a los perros parlantes, extraña conjunción entre figura de perro y razón humana, consideramos como principales aquellos personajes

sarrollo del ingenio y de las mañas para sobrevivir (J. J. Allen en la Introducción a su edición de Miguel DE CERvaNTES, El Ingenioso Hidalgo Don Quijote de la Mancha. Madrid, 1977, vol. I, pp. 19-20). Aunque este autor piensa que las Novelas Ejemplares se separan uradicalmente" de la picaresca, es evidente que el "Coloquio" presenta plenamente las tres primeras caracteristicas del género por él señaladas y en cierta medida también las dos restantes, aunque la estructura literaria de la novela es mucho más compleja que una simple autobiografía.

16 Casalduero, op. cit., p. 262.

17 A. Domfnguez Ortiz, Las clases privilegiadas en el Antiguo Régimen. Madrid, 1979 (2.: ed.), p. 187. 
que mantienen con Berganza una relación de amo-servidor. Son tales amos: el jifero Nicolás el Romo, los pastores, el mercader, el alguacil, el soldado atambor, los moriscos, los gitanos, el poeta y la compañía de comediantes.

A estos hay que añadir otros personajes principales: los negros que sirven en la casa del mercader, que aunque no son los amos directos de Berganza sí son los encargados de su cuidado, y la vieja hechicera de Montilla, con quien Berganza establece una profunda relación que dejará un gran impacto en su memoria, constituyendo el episodio culmen de la vida itinerante del perro. Junto a estos personajes aparece toda una legión de individuos, cuya importancia en el transcurso de la obra es secundaria.

Nicolás el Romo, jifero de profesión, es uno de los personajes individualizados con nombre propio. Reside y trabaja en el Matadero de Sevilla ${ }^{18}$. Es persona ruda y simplona, como bien indica el mote de "Romo». Físicamente es un "mozo robusto, doblado y colérico, como lo son todos aquellos que ejercitan la jifería" ${ }^{19}$. Es hombre violento y desalmado, de conciencia "ancha». Su cultura es la propia del mundo del hampa, del ambiente de corrupción y perversión de los bajos fondos de Sevilla.

Los pastores no aparecen individualizados, sino que se les trata como colectivo. Su oficio consiste en guardar el ganado, "obra -en opinión de Cervantes- donde se encierra una virtud grande, como es amparar y defender de los poderosos y soberbios los humildes y los que poco pueden" ${ }^{20}$. Su ambiente es el campo. Alli se describen como rudos y zafios, lo más distante que se pueda imaginar a la novela pastoril. Todo bucolismo se desvanece ante la contemplación de estos hombres que gritan y gruñen más que cantan, que pasan el día sesteando y espulgándose, a la vez que cosen sus remiendos. Pero la observación de Cervantes no se queda en estos aspectos pintorescos; la elevada misión que se les encomienda deriva en la más vil de las maldades: son traidores, son los ladrones (los «lobos») de las ovejas.

El mercader es el personaje principal más acomodado de la novela. Es padre de familia y tiene dos hijos, de doce y catorce años de edad respectivamente. Aunque no tiene nombre propio, sabemos que reside en Sevilla y trabaja en la Lonja, haciendo sus tratos y negocios. El ambiente que le rodea es de riqueza,

${ }^{18}$ El Matadero sevillano, extramuros de la ciudad junto a la Puerta de la Carne, era un kedificio integrado por un caserio con naves, corrales, miradores y una plaza donde se corrian y alanceaban toros en verano" (F. MORALES PADRÓN, Historia de Sevilla. La ciudad del Quinientos. Sevilla, 1977, (2.: ed.), p. 143.

19 Cervantes, Coloquio..., p. 302.

20 Ibidem, p. 305. 
como se manifiesta en la suntuosidad de su vivienda. De ella se mencionan los corrales, los terrados y la cocina, seguramente las estancias a las que Berganza tenía acceso. Cuando salían los hijos del mercader, lo hacían con gran "aparato" de sillas, coche, etc... Otro elemento de suntuosidad es la presencia de servidumbre, sobre todo de color ${ }^{21}$. Aunque ambicioso ante el porvenir de sus hijos, a los que envía al estudio de Gramática de los jesuitas sevillanos, el mercader es un hombre llano y austero en sus negocios y necesidades personales ${ }^{22}$.

Los negros constituyen personajes de ínfima condición social y también moral. Se dedican a la servidumbre doméstica, incluso alguno es de condición esclavo ${ }^{23}$. Aparecen sin individualizar y a juzgar por las tareas a que se dedican deben ser jóvenes. Lo que más resalta Cervantes son sus defectos: insolencia, latrocinio, mezquindad y deshonestidad.

El alguacil está claramente personalizado, aunque Cervantes evita decir su nombre. Reside en Sevilla y su oficio le permite recorrer diariamente las calles de la ciudad y, en especial, las áreas periféricas más conflictivas, como Triana, el barrio de San Julián o la Puerta de Jerez. Sus amigos pertenecen a los bajos fondos sevillanos: jiferos (Nicolás el Romo, por ejemplo), rufianes (bajo el mando de Monipodio), mujeres dedicadas a la prostitución y su inseparable compañero, el escribano, tan corrompido como él, cómplice de todos sus excesos y cohechos. Frecuenta

${ }^{21}$ Estos datos no son puramente anecdóticos, sino símbolos que se traducen en «un estilo de vida", siendo significativos del status social «tanto el tipo y ubicación de la residencia como el modo de vestir y los bienes de consumo utilizados, puesto que en todas las sociedades los actos y posesiones de los hombres tienen tres funciones diferentes: la función puramente instrumental, la estética y simbolizar sus diversas situaciones sociales» (B. Morell Peguero, Mercaderes $y$ artesanos en la Sevilla del Descubrimiento. Sevilla, 1986, p. 101).

${ }^{22}$ Entre las virtudes del comerciante extendidas por la época pueden mencionarse las que expone Savary en su «Le parfait négociant" (1697): conocimiento exacto de la materia, buen orden en los negocios, diligencia, ahorro y buena economía de la casa y formalidad en los negocios [En W. SombarT, El burgués. Madrid, 1977 (2:" ed.), p. 126]. La austeridad de la vida burguesa, ligada al espíritu capitalista, ha sido conectada a la ética del protestantismo. «Al oropel y relumbrón -escribe Weber- del fausto caballeresco que, apoyado en insegura base económica, prefiere la elegancia deslucida a la sobria sencillez, se opone ahora el ideal de la pulcra y sólida comodidad del "home" burgués" (M. WEBER, La ética protestante y el espiritu del capitalismo. Barcelona, 1969, p. 243). No es éste evidentemente el espíritu que anima al mercader del «Coloquion.

${ }^{23}$ «Es absolutamente cierto que la clase servil es mucho más numerosa en Andalucía que en ninguna otra parte de España, hasta el punto de que los castellanos de paso por Sevilla se van con la impresión de que los esclavos constituyen la mitad de la población» (M. DEFoURnEAUX, La vida cotidiana en la España del Siglo de Oro. Barcelona, 1983, p. 82). 
las posadas (casas de citas encubiertas) y los centros del hampa. Físicamente es un individuo ágil y brioso, síntomas de juventud. $\mathrm{Su}$ carácter es afable, amigo de bromas y muy ambicioso. Pero ante todo representa al funcionario corrompido, que acepta el soborno, que aprovecha su puesto en beneficio propio y que imagina las tretas más diversas para robar, de una manera especial a los extranjeros ${ }^{24}$.

El atambor es soldado de profesión, aunque vagabundo y titiritero de ocupación. No se caracteriza a este personaje con nombre propio. Es persona de origen humilde, especialmente por comparación con personajes de graduación más alta. Anteriormente había sido corchete y en la ficción novelada se nos presenta en una compañía que va a embarcarse a Cartagena. Berganza hace con él el camino entre Mairena del Alcor y Montilla. Es, en definitiva, un aventurero, carente de algo que pueda parecerse, ni ligeramente, al ideal caballeresco. La guerra es para él un medio de vida.

La hechicera, nombrada la Cañizares, es un personaje ya anciano, de setenta y cinco años de edad. Reside en la localidad de Montilla, donde subsiste como hospitalera. Se relaciona con otras brujas, la Camacha y la Montiela, ya fallecidas, de quienes ha adquirido sus conocimientos secretos. La descripción física que de ella hace Cervantes es magistral: «era larga de más de siete pies; toda era notomía de huesos, cubiertos con una piel negra, vellosa y curtida; con la barriga, que era de badana, se cubría las partes deshonestas, y aun le colgaba hasta la mitad de los muslos; las tetas semejaban dos vejigas de vaca secas y arrugadas; denegridos los labios, traspillados los dientes, la nariz corva y entablada, desencasados los ojos, la cabeza desgreñada, las mejillas chupadas, angosta la garganta y los pechos sumidos; finalmente, toda era flaca y endemoniadan ${ }^{25}$. La Cañizares es pobre. El trabajo de hospitalera le permite dedicarse al hurto, especialmente roba a los enfermos que fallecen. Tiene además cierta formación y una inteligencia muy penetrante. Ello se manifiesta en sólidos conocimientos de teología cristiana, si bien conoce que tales conoci-

${ }^{24}$ En la Sevilla de finales del siglo XVI y comienzos del XVII se ha constatado la existencia de varios procesos a alguaciles: en 1590 a uno llamado Quesada, que acabó en la hoguera acusado del pecado nefando, y hacia 1616 un alguacil de Brenes fue condenado a destierro por dedicarse a salteador de caminos. "No es éste el único -escribe por entonces el jesuita Pedro de León- de los que empuñan varas que sea compañero de ladrones" (En P. HerRera PugA, Sociedad $y$ delincuencia en el Siglo de Oro. Granada, 1971, p. 350). Recuérdese que Cervantes estuvo preso en la cárcel de Sevilla, donde pudo coincidir con el citado jesuita y donde debió conocer casos de alguaciles procesados como los anteriores.

25 Cervantes, Coloquio..., p. 344. 
mientos son puramente teóricos y que en manera alguna se reflejan en su comportamiento. Finalmente, se manifiesta como una maestra en el arte de fingir y engañar, lo que crea confusión entre quienes la conocen, problema que se acentúa en el contexto social en que vive, compuesto por gentes sencillas. Así, unos la tienen realmente por santa y otros por una malvada bruja.

El escritor trata a los gitanos como un colectivo. Se trata de personas de vida itinerante, cuyas ocupaciones son la ociosidad, el oficio de herrero, los ejercicios corporales y, sobre todo, el hurto. Berganza pasa con ellos veinte días, en un campo próximo a Granada, con lo que tiene ocasión de conocer sus costumbres y modo de vida. Como grupo o clase se caracterizan por fuerte endogamia y un marcadísimo espíritu de clan.

El morisco del "Coloquio" vive en una huerta a las afueras de Granada. Su ocupación es labrar su campo, de tierra de vega. En general, los moriscos destacaron en el campo de la horticultura. Es una persona mezquina y avara. Cervantes no individualiza a este personaje, sino que su aparición en la ficción le da pie para caracterizar, como más adelante se analizará, a este grupo en su conjunto: los moriscos.

El poeta carece también de nombre propio. Se trata de un mancebo, al parecer estudiante. Como poeta el desdichado es pobre. Vive en Granada, pero para concentrarse en sus composiciones se retira a las huertas de la vega, donde lo conoce Berganza. Después lo encuentra un día cuando salía del Monasterio de San Jerónimo, extramuros de la ciudad, comprendiendo al momento que era un pobre vergonzante. Sin embargo, lo más destacado es que se tiene por gran escritor y no lo es. "La comedia era tal -explica Berganza-, que con ser yo un asno en esto de la poesía me pareció que la había compuesto el mismo Satanás, para total ruina y perdición del mismo poeta ${ }^{26}$. Vive, pues, en un mundo imaginado, por lo que este personaje sirve de pórtico al tratamiento del mundo de la locura que traza en cuatro personajes posteriores, todos ellos de interés secundario.

Finalmente, Berganza llega a Valladolid después de haber pasado por tres compañías de comediantes. La primera de ellas tenía por autor a un tal Angulo el Malo ${ }^{27}$. Los comediantes aparecen caracterizados en su conjunto. Son personas de vida itinerante, de profesión actores y de carácter farsantes, en toda la

26 Ibidem, p. 353.

27 Ibidem, p. 353. Se trata de Angulo y los Corteses, quien hacia 1582 representaba comedias en Madrid (A. Gonzáles de Amezúa y Mayo en su edición de Miguel de Cervantes de SaAvedra, El casamiento engañoso y Coloquio de los perros. Madrid, 1912, p. 674). 
extensión de la palabra y no sólo cuando suben al escenario. Destaca de su modo de vida la ociosidad, la ignorancia, la agudeza y el fingimiento. En fin, son idólatras de la belleza, pero crueles con el perro.

\section{LA PIRÁMIDE SOCIAL}

Cada personaje o grupo ocupa un lugar específico en el esquema social tripartito comúnmente aceptado para caracterizar a la sociedad del Antiguo Régimen, basada en la existencia del privilegio. A este esquema hay que añadir los grupos marginados en función del concepto de casta ${ }^{28}$.

En el vértice de la pirámide social se encuentra el rey, señor de todos sus súbditos. Sus vasallos más directos son los miembros del estamento nobiliario. Ninguno de los personajes principales de la novela pertenece a la nobleza, pero sí algunos personajes secundarios. El más característico de ellos es el Marqués de Priego, señor de la casa de Aguilar y de Montilla; es un representante de la nobleza titulada. Además aparecen otros personajes que pueden adscribirse a estratos más bajos del grupo nobiliario. Así, el Asistente de Sevilla, su Teniente de Asistente, el capitán y el alférez de la compañía de soldados y el Corregidor de Valladolid poseen la calidad de caballeros ${ }^{29}$, incluyéndose algunos de ellos en el alto funcionariado.

Tampoco entre los personajes principales encontramos representantes del estamento eclesiástico. Se hace una mención al

${ }^{28}$ Gutiérrez Nieto cifra los rasgos que caracterizan a la estratificación castiza en: grupos definidos por su pureza religiosa, vinculación de funciones religiosas con el desempeño de ciertas profesiones, pertenencia por nacimiento, hermetismo manifestado por la endogamia y la incomunicabilidad, diferencias de tipo étnico, gran desarrollo de formas de imposición social y la diferente actitud hacia la Divinidad (J. I. GUTIÉRREZ NIETo, "La estructura castizo-estamental de la sociedad castellana del siglo XVI, en Hispania, núm. 125, 1973, p. 523). Entre los personajes del "Coloquio" sólo los moriscos (no aparecen judeoconversos) admiten la categoría de casta. No así los gitanos, si bien participan de algunas de las características indicadas.

${ }_{29}$ Los intentos por jerarquizar a los nobles han sido diversos. He aquí la clasificación elaborada por Domínguez Ortiz: situaciones prenobiliarias o de dudosa nobleza, hidalgos, caballeros, caballeros de hábito y comendadores, señores de vasallos, Títulos y Grandes de España (Domínguez ORTIZ,op. cit., p. 52). Del Censo de 1591 se desprende un 10 por 100 de población hidalga en el reino castellano, promedio engañoso si se atiende a su distribución geográfica. En el conjunto de Andalucía, el porcentaje era muy inferior al 5 por 100 (A. Domínguez OrTiz, El Antiguo Régimen: Los Reyes Católicos y los Austrias, vol. 3 de Historia de España. Madrid, Ed. Alianza, 1988, p. 160). 
Papa y a los cardenales, jerarquía de este grupo. Entre los personajes de menor importancia para la ficción novelada aparecen inquisidores y representantes del clero regular: los jesuitas, de consideración social elevada, y los hermanos de la "capacha", dedicados a la atención hospitalaria, que pertenecen al bajo clero. Nada respecto al clero secular, salvo una mención al sacristán, personaje híbrido que participa tanto del estado seglar como del eclesiástico ${ }^{30}$.

Abrumadoramente mayoritario en la sociedad española de la época que nos ocupa, el estado llano o tercer estado contenía en su seno la más variada complejidad. A este grupo pertenecen la mayoría de los personajes del "Coloquio", entre ellos todos los personajes principales.

En una clasificación más didáctica que real proponemos el siguiente escalonamiento.

En primer lugar, encontramos a los miembros acomodados del tercer estado, cuya distinción se basa en la riqueza y en la propiedad. Este es el caso del ganadero («señor del ganado») y del mercader sevillano, cuya aspiración es el ennoblecimiento de sus hijos.

A continuación habría que situar a los individuos pertenecientes al funcionariado medio y bajo. En conjunto, gozan de cierto prestigio social, tanto mayor cuanto escalaban un puesto superior en el "cursus honorum». Los jueces, por ejemplo, gozaban de gran prestigio. En cualquier caso, el funcionariado constituye un cuerpo bien jerarquizado. El alguacil y el escribano pertenecen a él, aunque en escalones inferiores. Además, pueden incluirse en este apartado otros personajes secundarios, como son los letrados y romancistas, objeto de una de las más agudas críticas cervantinas, y los cargos inferiores del ejército, como el de sargento, ocupados por personas de humilde extracción social.

El común del estado llano lo componen aquellas personas que atienden a un oficio o trabajo, generalmente manual, con cuyo producto sobreviven. Es la gran base de la pirámide social y de la economía del reino. Aquí podemos incluir a los pastores y labradores, al mesonero y a su esposa, a los ganapanes, a los co-

${ }^{30}$ "La frontera entre el mundo secular y el eclesiástico era muy fluida, más que la que separaba a nobles y plebeyos" (Domínguez ORTiz, Las clases..., p. 204). Según el citado Censo de 1591 el estamento eclesiástico en la Corona de Castilla no llegaba al 6 por 100, contabilizándose un total de 74.153 personas, de las que 33.087 eran clérigos seculares, 20.697 religiosos y 20.369 monjas (Domínguez ORTIZ, El Antiguo..., p. 168). 
merciantes y al poeta ("pobre vergonzante»), al verdugo (oficio generalmente mal visto), al autor de comedias o a los corchetes que acompañan al alguacil. Algunas de estas ocupaciones, como la de mesonero o la de comerciante, suelen considerarse como viles. El atambor es también un personaje procedente del común, aunque su modo de vida lo ha desclasado, pues la guerra lo hace salir de su entorno original para entrar antes en el mundo de los vagabundos que en el de las armas.

Otro colectivo, pese a su condición más humilde, podría incluirse en este apartado: la servidumbre. En la novela aparecen el ayo y los pajes de la casa del mercader y la criada de la posada. Su condición servil de carácter doméstico viene marcada, en última instancia, por la subordinación y dependencia, aunque parecen gozar de buen trato por parte de sus señores.

En el seno del estado llano hay personajes marginales. Algunos son marginados por sus prácticas de brujería, hecho que les acarrea la vergüenza de haber pasado por el tribunal de la Inquisición, como ocurre con la Cañizares y sus amigas brujas. Otros personajes se hallan marginados a causa de su locura; son desechos de la sociedad que viven apartados en el hospital, que más que centro asistencial y de curación es lugar de reclusión para los desheredados y lugar donde se va a morir ${ }^{31}$. Estos locos son el matemático, el poeta, el alquimista y el arbitrista recluidos en el Hospital de la Resurrección de Valladolid.

Finalmente están aquellos personajes marginados por sus actividades delictivas, es decir, los que se encuentran fuera de la ley. Son los bajos fondos, los dominios del hampa. Deben inluirse en este grupo los rudos jiferos, las mujeres dedicadas tanto al hurto como a la prostitución $\mathrm{y}$, en general, los numerosos rufianes de la Sevilla moderna, cuya cabeza visible es Monipodio. Son los representantes de la amarga realidad contrastual de la sociedad del Antiguo Régimen: frente a la riqueza procedente de Indias, la delincuencia, la mendicidad y la miseria ${ }^{32}$. En definitiva, se trata de una dura lacra social en el seno de la gran urbe y capital financiera del reino de Sevilla que con tanta cru-

${ }^{31}$ Por entonces la situación no debía ser muy distinta a la descrita por Sanz Sampelayo para el siglo XVII: «Sus enfermos aparecen en un marco deprimente en el que la falta de limpieza y ventilación, junto con el hacinamiento, representa el modelo más común y la circunstancia más clara para comprender el miedo que sentían aquellas gentes hacia dichos centros» (J. SANZ SAmpelayo, Granada en el siglo XVIII. Granada, 1980, p. 192).

32 was riquezas proporcionan toda clase de facilidades, al mismo tiempo que se convertían en posibilidades de vicio. En ellas se encontraban las fuerzas de la prosperidad y las graves sinrazones de la miseria” (HeRRerA PUgA, op. cit., p. 83). 
deza y verismo aparece reflejada en las obras del género picaresco ${ }^{33}$.

\section{LINAJE Y LIMPIEZA DE SANGRE}

El linaje es un principio operante en la sociedad el siglo XVII y como tal aparece en el "Coloquio", abordado por Cervantes desde una doble óptica: la hidalguía como ideal adornado de virtudes propias y la degeneración de este ideal por un afán indiscriminado de acceso a dicho estado.

El hidalgo es un personaje con determinadas cualidades inherentes a su status. El hidalgo en la Edad Moderna es, en buena parte, el caballero medieval, más o menos desnaturalizado por el transcurso del tiempo. ¿No representa don Quijote ese ideal llevado hasta el absurdo o quizás solamente hasta el extremo?

La hidalguía va unida al concepto de buena crianza, esto es, de comportamiento cortés y esmerada educación. Entre las "formas" de comportamiento propias del caballero está la piedad cristiana. El sentimiento religioso se presupone en todo caballero, porque el caballero medieval es el caballero cristiano. Todo hidalgo "auténtico" posee, pues, esta cualidad. Así, el capitán que manda la compañía en la que se encuentra el atambor es «muy buen caballero y gran cristiano»; el Marqués de Priego, dentro de la nobleza titulada, es hombre «famoso y gran cristiano»; también el Corregidor de la ciudad de Valladolid es «un gran caballero y muy gran cristiano" ${ }^{34}$.

En definitiva, la hidalguía no es tanto un estado social cuanto una forma de ser que se distingue por sí misma. Así, entre los agentes de la justicia, también umuchos y muy muchos hay hidalgos por naturaleza y de hidalgas condiciones" ${ }^{35}$. Tal vez por tratarse de una forma de ser (se es o no se es hidalgo) determinada por la cuna o el nacimiento, la hidalguía, en opinión de

${ }^{33}$ Según Santiago Montoto, «el más desolador de todos los cuadros lo formaban los niños, que hambrientos, casi desnudos, cubiertos por la roña y comidos de tiña acudían a los mercados y a las puertas de las casas de gula, para sustentarse con las sobras y vagar luego por el compás y la Mancebía, adiestrándose en las artes que habían de llevarles al verdugo o a las galeras de por vidaw (en ibidem, p. 85).

${ }^{34}$ Cervantes, Coloquio..., pp. 332, 334 y 358, respectivamente. Aquí puede rastrearse una consideración de tipo social entroncada con el concepto de casta: «sólo la nobleza tradicional -escribe Gutiérrez Nieto- será capaz de exigir la doble dimensión de la limpieza: cuna limpia o vida limpia», es decir, limpieza de sangre y ocupación y virtudes nobiliarias (GUTIÉRREZ NIETO, op. cit., p. 550).

35 Cervantes, Coloquio..., pp. 327-328. 
Cervantes, no puede adquirirse por compra o gratificación. En este sentido, se sitúa en una postura de defensa de los valores de la nobleza tradicional o de sangre.

Sin embargo, Cervantes testimonia el afán de las clases sociales no privilegiadas por ennoblecerse, por intentar "ser como". Este es el caso de la incipiente burguesía comercial. El mercader sevillano al que sirve Berganza no manifiesta su riqueza en su persona, sino en la de sus hijos, "porque los mercaderes son mayores en su sombra que en sí mismos». Su ambición y ostentación encuentra, pues, un cauce adecuado a través de sus hijos, a los que "tratan y autorizan como si fuesen hijos de algún príncipe; y algunos hay que les procuran títulos y ponerles en el pecho la marca que tanto distingue la gente principal de la plebeya" ${ }^{36}$. Es la ambición de ennoblecimiento, que aunque "generosa", siempre supone "daño de tercero".

El linaje, confundido con el concepto de casta, llega a ser la obsesión española en la Edad Moderna. Los estatutos de limpieza de sangre son una realidad cotidiana. Hasta para tomar criados, relata Cipión, los señores «les espulgan el linaje». La crítica cervantina se hace aquí solapada: para servir a los hombres se busca el de mejor linaje (limpieza de sangre), para servir a Dios basta la «limpieza de corazón».

El concepto «limpieza de sangre" conduce a otro que se ha llamado «limpieza de oficios». Igual que el linaje marca al hombre, también su oficio. Hay ciertamente oficios viles (generalmente los trabajos mecánicos y de más baja consideración), que marginan a amplios sectores de la sociedad. Esta "limpieza» constituye un principio realmente operante. ¿Cómo puede conjugarse la hidalguía con el desempeño de un oficio vil? Esta es la pregunta que hace prorrumpir en carcajadas al Teniente de Asistente de Sevilla, cuando la huéspeda de la posada le presenta la ejecutoria de hidalguía: "Hermana camera, yo quiero creer que vuestro marido tiene carta de hidalguía con que vos me confeséis que es hidalgo mesonero" ${ }^{37}$.

El desorganizado afán por aspirar a la hidalguía está corrompiendo este estamento. La hidalguía degenera a lo largo de la Edad Moderna, en parte por su propio proceso de inflación. Es la otra cara, pesimista, de la hidalguía. La sátira de Cervantes se muestra atroz. La ambición se lleva al extremo. La referida huéspeda de la posada (casa de citas) asegura ser esposa de un principal hidalgo y cuando se encuentra en posición apurada por

${ }^{36}$ Ibidem, p. 314.

37 Ibidem, p. 327. 
la presencia del alguacil en su posada, pretende encontrar la panacea para el problema, o sea la prueba de su inocencia, en la carta de ejecutoria de su marido, "con a perpenan rei de memoria" y "con sus colgaderos de plomo".

Muchos individuos presumían de hidalguías que nunca tuvieron. Los procesos judiciales son innumerables, todos tras el afán de probar una hidalguía, dudosa cuando menos, incierta en numerosos casos. Pero las aspiraciones de la posadera son ya la antitésis del ideal de hidalgo. Se presume de lo que no se tiene y se llega al absurdo. Polémica que la huéspeda cierra con esta atrevida expresión: "¿qué linaje hay en el mundo, por bueno que sea, que no tenga algún dime y direte?" ${ }^{38}$.

\section{GRUPOS MARGINADOS}

Además de aquellos personajes que pueden considerarse marginales dentro del estado llano (hampa, prostitutas, locos...), cuya marginación suele ser de tipo personal, existen otros que sufren una marginación social grupal: los negros, a causa de su raza; los gitanos, en razón de su étnia y sus costumbres, y los moriscos en virtud de su casta de cristianos nuevos. Negros, gitanos y moriscos comparten la animadversión de Cervantes y de un amplio sector de la sociedad.

Los negros abundaban, como criados o como esclavos, en las casas de la alta sociedad sevillana ${ }^{39}$. En la casa del mercader de la novela, varios negros forman la servidumbre: un criado que le acompaña a sus negocios en la Lonja, una negra dedicada a las tareas domésticas de la cocina, que daba de comer a Berganza, y otro negro, "esclavo de casa" que dormía en el zaguán, posiblemente encargado del servicio de portería. La servidumbre negra recibe un trato digno por parte de su amo.

Berganza los acusa, en conjunto, de "mezquindad", «insolencia, ladrocinio y deshonestidad». La negra es mezquina porque se limitaba a dar al perro estrictamente su ración "perruna». Es ladrona porque para ver al negro del que estaba enamorada (el mismo que dormía en el zaguán), había hurtado y contrahecho

38 Ibidem, p. 327.

39 La esclavitud era práctica frecuente en el siglo XVI, sobre todo en el suroeste español. Se calcula que en la segunda mitad de esa centuria por cada diecisiete sevillanos había un esclavo, arrojando el censo de 1565 el porcentaje del 6 por 100 del total de la población de la ciudad (MORALES PADRÓN, op. cit., p. 103). Pero no todos los esclavos eran negros o mulatos; los había también moriscos, canarios, americanos, etc... 
las llaves. Era deshonesta porque se veía con él de noche en secreto, a escondidas de su amo, pues «bajaba... a refocilarse con el negro", "con quien se daba buen tiempo, facilitándolo mi silencio, y a costa de muchas cosas que la negra hurtaba" ${ }^{40}$. Insolente, en fin, por abusar de la «liberalidad" de su amo, disimulando y, aún más, sobornando a Berganza para franquear la puerta en sus excursiones nocturnas, confiada en que lo enmudecerían los pedazos de carne, pan o queso que le arrojaba.

Muchos días tuvieron estas dádivas «mudo" a Berganza, pero al fin decide actuar. Cuanto más deseaba desvelar la verdad, mejor fingía la negra y crecía su odio hacia el perro. Eran batallas a la sorda con mi "perra", calificativo que le da Berganza. El triunfo final fue para la negra, pues el perro veía cómo menguaba su ración y cómo ella trataba de deshacerse de él con premura.

Los gitanos constituyen, en opinión de Cervantes, un colectivo muy pernicioso para la sociedad. En primer lugar, destaca su elevado número y su fuerte espíritu de clan: «¿Ves la multitud que hay dellos esparcida por España? - dice Berganza- Pues todos se conocen y tienen noticia los unos de los otros" ${ }^{4}$.

Dicho espíritu de clan se encuentra reforzado por dos cualidades: una severa disciplina interna y un marcado comportamiento endogámico. La disciplina deriva de un férreo sentimiento de obediencia jerárquica: «dan la obediencia, mejor que a su rey, a uno que llaman Conden, un tal Maldonado, paje blanco que por amor se hizo gitano. Dejando aparte la leyenda, lo cierto es que a dicho Conde, "como en señal de vasallaje, le acuden con parte de los hurtos que hacen", en un gesto de contribución económica al mantenimiento de esa pseudo-casa real, de lo que derivan graves implicaciones políticas. Por otro lado, constituyen un grupo cerrado, en el que la endogamia es una práctica más que habitual: «cásanse siempre entre ellos, por que no salgan sus malas costumbres a ser conocidas de otros; ellas guardan el decoro a sus maridos, y pocas hay que les ofendan con otros que no sean de su generación". En el campo familiar la honra es un elemento vital, mantenedor de esa disciplina de grupo.

En resumen, el espíritu de clan acaba constituyendo al grupo en un elemento extraño y particular, un estado dentro del Estado. Su existencia adquiere una dimensión política, como lo demuestra

40 Cervantes, Cologuio..., pp. 322 y 320, respectivamente.

41 El pasaje referente a los gitanos se encuentra en Coloquio, pp. 346-349, a las que corresponden las abundantes citas textuales que, por su especial viveza, reproducimos en este apartado. 
la abundante legislación antigitana promulgada durante la Edad Moderna ${ }^{42}$.

¿Cuáles son las ocupaciones de los miembros de este colectivo? Primeramente hay que señalar su desocupación, es decir, su ociosidad; muchas de las mujeres "dan en ser holgazanas". Esta ociosidad permite dedicar el tiempo a pensar y «son sus pensamientos imaginar cómo han de engañar y dónde han de hurtar; confieren sus hurtos, y el modo que tuvieron de hacellos». También consta su presencia en el oficio de herrero. Cervantes explica cómo se ocupan, "por dar color a su ociosidad, en labrar cosas de hierro, haciendo instrumentos con que facilitan sus hurtos". Entre los objetos de su producción se encuentran tenazas, barrenas, martillos, trebedes y badiles.

Otra ocupación consiste en ejercitarse en exhibiciones circenses con fines lucrativos; son volteradores, corredores y bailadores. A ello hay que añadir el espectáculo de títeres; son, pues, titiriteros. Se trata de ocupaciones itinerantes que les permiten conocer mundo y desarrollar con éxito sus malas artes, impidiendo un mínimo control por parte de la maquinaria estatal. Las mujeres, además, suelen ser parteras, desarrollando en este campo, no técnicas especiales, sino una tradición remota, de forma que "sin costa ni ad(h)erentes sacan sus partos a luz, y lavan las criaturas con agua fría en naciendo».

En cualquier caso, el oficio por antonomasia de este grupo es, para Cervantes, el robo, su principal forma de vida. Las restantes ocupaciones se dirigen primordialmente a "facilitar sus hurtos». Esto los convierte en un colectivo prácticamente al margen de la ley. Están especializados en el robo de bestias, «en quien son ellos graduados y en los que más se ejercitan». El mismo Berganza fue objeto de este vicio: «me acogieron y escondieron en una cueva, por que no me hallasen si fuese buscado, con intención... de ganar conmigo como lo hacía el atambor mi amo".

También son duramente criticadas sus costumbres. La crianza de los niños es de especial crudeza; con ella «se curten y muestran a sufrir las inclemencias y rigores del cielom. Su comportamiento religioso, por otra parte, es prácticamente inexistente: «pocas o ninguna vez he visto - habla Cervantes por boca de Berganza-, si mal no me acuerdo, ninguna gitana a pie de altar

${ }^{42}$ Esta legislación se rastrea durante todos los reinados desde los Reyes Católicos hasta Carlos IV, con la única excepción de Felipe IV, siendo de especial dureza la Pragmática Sanción promulgada en 1783, reinando Carlos III. Sobre la legislación antigitana, vid. M." H. SÁNCHEZ ORTEGA, Documentación selecta sobre la situación de los gitanos españoles en el siglo XVIII. Madrid, 1976, pp. 30-97. 
comulgandow. Son, en fin, locuaces y amigos de enredar, con lo que obtienen beneficios económicos; de este modo, kcuando piden limosna, más la sacan con invenciones y chocarrerías que con devociones; y a título que no hay quien se fíe dellas".

Un grupo así, que vive del hurto y del engaño, es, en opinión de Cervantes, una lacra social. Los calificativos hacia quienes destacan por «sus muchas malicias, sus embaimientos y embustes, los hurtos en que se ejercitan... desde el punto casi que salen de las mantillas y saben andarn, son realmente duros: kella es mala gente - sentencia Berganza-, y aunque muchos y muy prudentes jueces han salido contra ellos, no por eso se enmiendanw.

La población morisca también merece el desprecio del autor. En primer lugar, es perjudicial por su proliferación, ya que «todos se casan, todos multiplican, porque el vivir sobriamente aumenta las causas de la generación" ${ }^{43}$. Berganza se alarma de esta cualidad y los compara con el pueblo judio en su cautiverio egipcio: doce entraron en tierras del faraón y setecientos mil varones salieron. De ello use podrá inferir lo que multipliarán los destos, que, sin comparación, son en mayor númeron.

Su modo de vida está presidido por la austeridad y la moderación, que, en este caso, nada tienen de virtud, pues responden a una avaricia desmedida: «todo su intento es acuñar y guardar dinero acuñado, y para conseguirle trabajan y no comen; en entrando el real en su poder, como no sea sencillo, le condenan a cárcel perpetua y a escuridad eternaw. Por ello, el morisco al que entra a servir Berganza era "mezquino, como lo son todos los de su castaw. Mal alimentaba al perro con pan de mijo y sobra de gachas. La austeridad y sobriedad de vida llega al extremo de que, aun teniendo grandes riquezas, kno tienen criados, porque todos lo son de sí mismos" ${ }^{4}$.

${ }^{43}$ De los moriscos se trata en las pp. 349-350 del «Coloquiow, en las que se contienen las palabras textuales que citamos en los próximo párrafos. La negativa opinión de Cervantes sobre el grupo morisco aparece también en los tratadistas que abordan el tema en el siglo xvn (Bleda, Fonseca, González de Cellórigo, vasconcellos, Ripoll, Pérez de Culla, etc...), todos ellos después de 1609: kconsideran la medida justa, necesaria y religiosamente imprescindible. Gracias a ella poseemos un país del que, en el sentido más estricto, se han desterrado los herejes, apóstatas y traidores" (M. A. DE BUNES, Los moriscos en el pensamiento histórico. Madrid, 1983, p. 17). Se trata, pues, de una historiografía apologética, a la vez que evidencia una opinión generalizada. En el mismo Cervantes se observa una evolución desde una postura más dura hacia cierta suavización del tema en la segunda parte del «Quijote» (ibidem, p. 21).

4 «egún los ideales de la sociedad cristiana, la laboriosidad, la frugalidad y la fecundidad de la familia son otros tantos bienes y virtudes. Ahora bien, estas mismas virtudes sirven de bandera contra los moriscos y no sólo porque la laboriosidad, la frugalidad y la fecundidad les fortalecían, sino también porque 
Aplican estas máximas, en contraste con el mercader sevillano, no sólo a sus personas, sino también a las de sus hijos, pues «no gastan con sus hijos en los estudios, porque su ciencia no es otra que la de robarnosw. He aquí el fondo de la cuestión y de la opinión cervantina. Suponen un elevado daño para la economía española, a la vez que una carga onerosa.

El daño no procede de su inactividad o desocupación. Al contrario, la laboriosidad de los moriscos, incluso para el mismo Cervantes, pasa por ser proverbial, especialmente en lo referente a labores de horticultura ${ }^{45}$. El daño procede, por el contrario, del atesoramiento de grandes sumas de dinero, apartándolas de la circulación productiva, de forma que uganando siempre y gastando nunca, llegan y amontonan la mayor cantidad de dinero que hay en Españaw. El problema se agrava por su número: "como van creciendo, se van aumentando los escondedores, que crecen y han de crecer en infinito, como la experiencia lo muestra" ${ }^{46}$.

De lo anterior, se deduce que para Cervantes se trata de un problema de orden eminentemente político, ya que la presencia del elemento morisco va en detrimento del bienestar de la nación. El juicio cervantino es muy duro: los moriscos son para España «su hucha, su polilla, sus picazas y sus comadrejas; todo lo llegan, todo lo esconden y todo lo traganw. Puede rastrearse en este pensamiento la idea medieval de usurpación, de apropiación de algo

en el grado en que ellos las tenían se consideraban como vicios: la laboriosidad estaba producida por cicatería, la frugalidad era avaricia, la fecundidad resultado de la lujuriaw [J. CARo BAROJA, Los moriscos del Reino de Granada Madrid, 1985 (3.: ed.), p. 215].

45 «El morisco hortelano se convirtió en un tópicon, sobre todo en el regadío, donde udesplegaban todas sus facultades de paciencia, destreza y laboriosidad", cualidades que parecen derivar de una remota herencia cultural y de la necesidad de obtener el máximo rendimiento del suelo, lo que les llevó a practicar una agricultura intensiva (A. DOMf́ngUez ORTIZ y B. VINCENT, Historia de los moriscos. Vida y tragedia de una minoría. Madrid, 1978, pp. 111-112).

46 Dominguez Ortiz y Vicent avanzan la cifra de entre cien y ciento veinte mil moriscos a finales del siglo XvI (ibidem, p. 81). Por su parte, Lapeyre habla de unos 300.000 residentes en España al momento de la expulsión, correspondiendo a Granada sólo 3.000, frente a los 61.000 de Aragón o los 135.000 de Valencia. Los expulsados rondaron los 275.000 , es decir, casi la totalidad del colectivo (H. LAPEYRE, Geografía de la España morisca. Valencia, 1986, pp. 251-254). En cuanto al reino de Granada, tras la expulsión de 1570, continuaron muchos en su interior, de diez a quince mil hacia 1580 . En enero de 1584 se produjo una nueva expulsión que afectó a 3.000 ó 3.500 personas. «Los miles que quedaron vieron crecer su número por los regresos clandestinos, que no cesaron nunca" (B. VINCENT, aLos moriscos que permanecieron en el Reino de Granada después de la expulsión de 1570w, en su obra Andalucia en la Edad Moderna: economia y sociedad Granada, 1985, pp. 284-285). 
que no les pertenece; en otras palabras, la consideración del elemento musulmán y sus descendientes, en este caso los moriscos, como algo extraño a la realidad peninsular. "Robannos a pie quedo - se lee en el "Coloquio" - y con los frutos de nuestras heredades, que nos revenden, se hacen ricosw. Son una carga onerosa porque trabajan por y para su interés particular y en nada contribuyen al de la comunidad. Por ejemplo, «no los consume la guerra, ni ejercicio que demasiadamente los trabaje». Constituyen, en definitiva, un grupo de nula utilidad pública.

A todo ello hay que añadir su perniciosa conducta religiosa, mal ejemplo en el seno de la monarquía católica. Su conversión no pasa der ser fingida, carente de autenticidad: "por maravilla -escribe Cervantes - se hallará entre tantos uno que crea derechamente en la sagrada ley cristianaw. Su actitud religiosa se convierte, en opinión del escritor, en un estado continuo de indiferencia, ya que "entre ellos no hay castidad, ni entran en religión ellos ni ellas".

En tales aseveraciones, exageradas a simple vista y carentes de verdad, no deja de manifestarse el espíritu de cristiano viejo y la actitud despreciativa hacia el elemento converso de Cervantes y de un destacado sector de la sociedad española. No podemos dejar de ver en el escritor al hombre que se batió en Lepanto contra las tropas del Islam, cuyas secuelas físicas sufriría el resto de su vida, además de padecer un largo cautiverio en manos de los piratas argelinos. Los apelativos son, desde luego, contundentes: "morisma canalla", "víboras" de España.

En suma, Cervantes plantea el tema morisco en el "Coloquio" desde la óptica del cristiano viejo, denunciando los daños que este colectivo ocasiona a la nación, "que bien sé - sentencia $\mathrm{Ci}$ pión- que son más y mayores los que callas que los que cuentas». Analiza el fenómeno en sus distintas implicaciones: religiosa, política y económica, concluyendo con la afirmación de que "celadores prudentes tiene nuestra república, que... ayudados de Dios hallarán a tanto daño cierta, presta y segura salida».

Es un vaticinio. Esa "presta y segura salida" no es otra que la expulsión de los moriscos de los territorios hispánicos, decretada por Felipe III el 22 de septiembre de $1609{ }^{47}$.

47 El mismo Cervantes alaba esta decisión poniendo esta profecía en boca de un morisco de su Persiles, poco después de la expulsión: «cerca de estos tiempos reinaría en España un Rey de la Casa de Austria, en cuyo ánimo cabría la dificultosa resolución de desterrar los moriscos de ella, bien así como el que arroja de su seno la serpiente que le está royendo las entrañas, o bien así como quien aparta la neguilla del trigo, o escarda o arranca la mala yerba de los sembrados* (en M. HeRrero GARctA, Ideas de los españoles del siglo XVII. Madrid, 


\section{UNA APROXIMACIÓN A LAS MENTALIDADES}

Desde no hace mucho más de dos o tres décadas, se está hablando de historia de las mentalidades. Lo específico del tema no supone una novedad radical, pues ya algunos historiadores se habían movido en este difícil campo de las mentalidades. ¿De qué si no trataba la obra de Huizinda y en gran medida la historia de la cultura que propugnaban historiadores como Crouzet?

A nuestro juicio, el tema nuevamente suscitado presenta dificultades aún superiores a las de la historia social. Dificultades que surgen de su propio contenido. La mentalidad es algo introspectivo, queda siempre en las mentes y muy pocas veces en los escritos, salvo las ideas de personas destacadas (una minoría) expresan por escrito. Por ello, rasgos de mentalidad en sentido amplio, es decir ideologías, opiniones, creencias y hasta sentimientos, difícilmente podrán rastrearse en la documentación oficial. El uso de las fuentes notariales, y en general de documentación privada, se manifiesta fructífero, pero su alcance es claramente limitado.

El historiador no puede por ello ignorar esta faceta de la historia del hombre, especialmente cuando las ideas, de una manera o de otra, siempre se reflejan en su comportamiento. Ideas, creencias o sentimientos configuran los códigos mentales, que actúan en dos sentidos, por vía de armonización o por vía de contradicción, pues nunca entre idea y conducta se establece una estricta relación de causa-efecto. Las mentalidades constituyen de este modo un campo muy complejo, a la vez que globalizante, de la vida del hombre ${ }^{48}$.

Al historiador no le interesa la mentalidad en abstracto, sino el horizonte mental de las personas que vivieron en un tiempo y en un lugar determinados, horizonte que entra en la dinámica de la larga duración. No puede negarse que las instancias superiores, tanto eclesiásticas como civiles, influyen en la configura-

1928, pp. 581-582). En cuanto a las consecuencias de la expulsión, tradicionalmente se ha señalado su incidencia negativa en la economía. Sin embargo, los juicios son diversos. Para Hamilton, en base a series de precios de productos agrarios y de jornales en Andalucía, ula expulsión no arruinó la agricultura andaluza, ni especificamente su horticultura", si bien el impacto debió ser más acentuado en Valencia [E. J. HAMmLTON, «Las consecuencias económicas de la expulsión de los moriscosw. en Actas del I Congreso de Historia de Andalucia. Andalucía Moderna (siglos XVI-XVII), vol. II. Córdoba, 1978, p. 79).

${ }^{48}$ La historia de las mentalidades use sitúa en el punto de conjunción de lo individual con lo colectivo, del tiempo largo y de lo cotidiano, de lo inconsciente y lo intencional, de lo estructural y lo coyuntural, de lo marginal y lo general» [J. LE GOFF, "Las mentalidades. Una historia ambigua" en J. LE GoFF, y P. NoRA, (edits.), Hacer la historia. Barcelona, 1980, vol. III, p. 85]. 
ción de una mentalidad dominante. Pero tampoco debe olvidarse que esa influencia nunca la configura en toda su realidad y complejidad. Así, creemos que la mentalidad que caracteriza al hombre del siglo XVII es en gran medida resultado de la herencia medieval anterior incluso a la aparición del Estado moderno o la reforma de Trento.

Si los fondos de archivo tienen una utilidad limitada, la Literatura, también con su limitación, ha sido, es y creemos será, en sus distintos géneros (sobre todo cuando está impregnada de realismo), la fuente primordial en esta parcela ${ }^{49}$. El estilo puede deformar la realidad, pero también la manifiesta por contraste. Este artificio barroco, presente ya en Cervantes, nos permite utilizar con legitimidad y a la vez con precaución el «Coloquio de los perros" como fuente para una aproximación a la mentalidad de la época en que aparece ${ }^{\text {so. }}$.

En este sentido, escribe $M$. Defourneaux: usi la novela picaresca no es para la sociedad y la vida española en el Siglo de Oro más que un espejo deformante, no por ello deja de ser la expresión de una España que evaluando la inmensidad de sus esfuerzos y la variedad de los resultados obtenidos, se pregunta acerca de sí misma y de su destinow ${ }^{51}$.

\section{VIDA, RAZÓN Y COMUNICACIÓN}

El «Coloquio» nos brinda una amplia gama de posibilidades para profundizar en la mentalidad de la época. Nos ceñiremos por el momento al estudio de la vida y las distintas valoraciones de ella, a la razón como principio conformador y a la comunicación como vehículo de la razón e instrumento de denuncia.

Entre las características principales de la prosa cervantina destaca el vitalismo. Las «Novelas» constituyen en sí mismas una encrucijada en la que confluyen las vidas más diversas, personajes

49 Entre las fuentes «privilegiadas" para la historia de las mentalidades se encuentran la literatura y el arte (ibidem, pp. 92-93). Así lo deja claro Escandell Bonet cuando señala ala importancia capital de la producción literaria como documento de estudio histórico de las actitudes mentales, de la comunicación social, la crítica política, la lucha ideológica, la formación de la opinión pública, etc." (en el Prólogo a la obra de M. Avmés, Sueños ficticios y lucha ideológica en el Siglo de Oro. Madrid, 1981, p. 20).

so Vovelle señala el riesgo principal del uso de la literatura como fuente para la historia: tomarla como utestimonios elementales reflejos de la realidad social vividaw, que aportan datos inocentes y únicos (M. Vovelle, Ideología y mentalidades. Barcelona, 1985, p. 43).

51 Defourneaux, op. cit., p. 220. 
que se muestran en su plena vitalidad ${ }^{52}$. La vida parece alcanzar un elevado valor para Cervantes. Su propia biografía así lo atestigua. ¿Qué consideración merece la vida a los personajes del "Coloquion?

Tal consideración aparece pintada en tonos muy grises, que van desde el nulo valor que le concede el jifero desalmado hasta el pesimismo existencial de una vieja bruja, cuya vida se encuentra, según piensa ella, «determinada» por el mal.

En los bajos fondos, la vida goza de nula consideración. Se trata de algo difícil de conservar, pues puede perderse con facilidad. Allí impera el más fuerte. Así ocurre en el Matadero sevillano, en el que los jiferos, "gente ancha de conciencia" y "desalmada", "con la misma facilidad matan a un hombre que a una vaca" $y$ "meten un cuchillo... por la barriga de una persona, como si acocotasen un toro" ${ }^{53}$. Matar es el oficio por antonomasia del Matadero. La muerte y la violencia son un espectáculo habitual, de forma que upor maravilla" transcurre algún día sin que haya que lamentar alguna muerte violenta.

La vida es fugaz y tiene un ritmo propio que escapa al control de los hombres. Es, pues, un paso, una evolución, que muchos ven con escepticismo y aún con pesimismo, actitudes ambas típicamente barrocas. "Todas las cosas pasan -explica la vieja hospitalera-; las memorias se acaban, las vidas no vuelven, las lenguas se cansan, los sucesos nuevos hacen olvidar los pasados" ${ }^{54}$.

En realidad, estos ejemplos evidencian dos visiones distintas, aunque negativas de la vida. La desconsideración por la vida ajena es una tónica en el ambiente de los jiferos; su raíz es estrictamente animal, esto es instintiva. Por el contrario, el pesimismo vital de la vieja hechicera es más que nada una actitud moral que ella misma reconoce. En este sentido, la vida es un tránsito abocado al mal, al vicio. La vieja advierte cómo la vida "corre sobre las ligeras alas del tiempon y se acaba, por ello confiesa: whe querido dejar todos los vicios de la hechicería en que estaba engolfada muchos años había, y sólo me he quedado con la curiosidad de ser bruja” ${ }^{55}$.

52 «El Coloquio, que tiene lugar en las horas de una noche, contiene toda una vida, toda la vida; para la angustia de la vida, el atosigamiento de la brevedad de las horasw (CASAldUERO, op. cit., p. 41).

${ }^{33}$ Cervantes, Cologuio..., pp. 302-303.

54 Ibidem, p. 343. Defourneaux explica la vida del español de esta época, en su dimensión personal y social, como conformada por dos principios básicos: el honor y la fe (DEFOURNeAUX, op. cit., p. 29).

53 Cervantes, Coloquio..., p. 338. 
Su vida camina inexorablemente hacia la muerte, que presiente ya cercana, aunque no aparece como traumática. La Montiela, su amiga bruja, murió "con tal sosiego y reposo, que si no fueron algunos visajes que hizo un cuarto de hora antes que rindiese el alma, no parecía sino que estaba en aquella (hora) en un tálamo de flores" ${ }^{56}$. Visión esperpéntica que consuela a la hechicera, consciente de la cercanía de su "acabamiento" y que espera, estoicamente, que venga la muerte y se la lleve de esta "cansada vida".

Al panorama de las vidas vacías, opone Cervantes el modelo de la vida racional. En la novela, los perros protagonistas, auténticos perros cuerdos, representan la racionalidad. La razón es la prerrogativa privativamente humana, ya que "la diferencia que hay del animal bruto al hombre es ser el hombre animal racional, y el bruto, irracional». Por esta razón, para Cipión y Berganza el hecho de poseer racionalidad, al menos momentáneamente, constituye una "cosa sobrenatural y jamás vista" ${ }^{57}$.

Salidos de la ignorancia, se comportan como personas racionales. Esta es la paradoja sobre la que se sustenta la ficción novelada: una auténtica trasposición de papeles. La animalidad de Cipión y Berganza se transforma en racionalidad y sentido común en medio de un mundo en que los seres humanos parecen carecer de estas cualidades. Es el baluarte desde el que se ejerce la crítica de Cervantes.

En el ámbito de lo racional confluyen una serie de facultades humanas, que, en el transcurso de una noche, adquieren también los perros. Entre ellas se encuentran el entendimiento, la memoria y la conciencia. El entendimiento mejora con el adiestramiento, o sea con la enseñanza; el mismo Berganza recuerda "cuando estudiaba". La memoria, por otra parte, es una cualidad humana, aunque se presenta en algunos animales, como los perros. "Lo que yo he oído alabar y encarecer - dice Cipión- es nuestra mucha memoria, el agradecimiento y gran fidelidad nuestra». Pero la memoria de Berganza, animada de un juicioso raciocinio, va más allá. Otra cualidad privativamente humana es la conciencia, de la que también gozan los perros. Esta es fácil de estragar, como reconoce Berganza: «algunos días me estragaron la conciencia las dádivas de la negra" ${ }^{58}$.

Muchas otras cualidades humanas se resaltan en los protagonistas: la capacidad de admiración ("quedé atónito y confuso»), la sensación de asco ("quise morderla... y no hallé parte en toda

56 Ibidem, pp. 340-341.

57 Ibidem, pp. 229 y 309, respectivamente.

58 Ibidem, pp. 300 y 320, respectivamente. 
ella que el asco no me lo estorbase») o la actitud de temor («me dio gran temor verme encerrado en aquel estrecho aposento") ${ }^{59}$. En definitiva, la ficción novelada, cercana a picaresca a la vez que a la fábula, no hace más que valorar, aunque por contraste o contraposición, las cualidades propiamente humanas.

El habla, es decir la capacidad de comunicación, goza de una consideración especial entre ellas. En primer lugar, la comunicación (diálogo) constituye la base de la ficción, la máxima expresión de la racionalidad de los perros. Por eso son continuas las alabanzas a este "divino don de la habla», un "bien" que tienen de prestado, pues esta facultad es en perros un "caso portentoso y jamás visto", hasta el punto de hacer exclamar a Berganza: «no sólo no me maravillo de lo que hablo, pero espántome de lo que dejo de hablar" ${ }^{60}$.

De estas expresiones se desprende la alta significación que concede el escritor a la comunicación, lo que se manifiesta incluso en la forma dialogada de la ficción. La palabra mueve a los hombres; por ello su uso ha de tener una doble finalidad: enseñar y deleitar a un mismo tiempo. En el pensamiento de Cervantes, quizás en el de todos los escritores del Siglo de Oro, subyace el convencimiento de que la palabra no es vana ni el cuento inútil. No basta con relatar, hay también que «filosofar", pues, en caso contrario, "no sería mi historia cabal ni de fruto alguno". Tal es la intención de Cervantes en sus Novelas Ejemplares, llamadas así porque "no hay ninguna de quien no se pueda sacar un ejemplo provechoso", un "sabroso y honesto fruto... así de todas juntas, como de cada una de por sín ${ }^{61}$.

No por atender al fin debe descuidarse el medio en el uso de la palabra. La expresión oral y escrita alcanza la máxima consideración en el pensamiento cervantino. La comunicación amena es un arte que requiere ciertas técnicas de dicción y escritura, que Cipión se atreve a apuntar a Berganza. En general, «los cuentos unos encierran y tienen la gracia en ellos mismos; otros en el modo de contarlos». Según los casos, se precisarán "preámbulos y ornamentos de palabras", "mudar la voz», "demostraciones del rostro y de las manos", etc... ${ }^{62}$. Estamos ante la variedad de técnicas de la oratoria barroca.

En la filosofía cervatina sobre la palabra y la comunicación subyace la importancia de su fin. La palabra al servicio de la virtud alcanza para él su máxima significación (deleitar y en-

\footnotetext{
59 Ibidem, pp. 336 y 344.

60 Ibidem, p. 310.

61 M. DE Cervantes, Novelas Ejemplares, ed. cit., vol. I, p. 52 («Prólogo al

${ }^{62}$ Cervantes, Coloquio..., p. 304.
} lectorw). 
señar). Por el contrario, la palabra al servicio de la murmuración corrompe (echa a perder linajes y calumnia a los buenos). Además, la palabra refleja la calidad de las personas. Mientras los «circunloquios y rodeos" causan asco al oirlos, «las honestas palabras dan indicio de la honestidad del que las pronuncia o las escribew.

En definitiva, la palabra honesta, o sea dignamente utilizada, es un sumo bien, la luz que alumbra a los hombres. Por eso, la palabra no puede desligarse de la razón, en un postulado próximo al de los ilustrados: la palabra ilumina y por esto knos hemos de quedar a escuras, faltándonos la hablaw ${ }^{63}$.

\section{ACTITUDES DE DENUNCIA Y REBELDIA}

Siempre que no se caiga en la murmuración, la palabra, en opinión de Cervantes, cumple con su alto fin cuando bosqueja una crítica razonada. Por ello no debe privarse a la palabra de la actitud de denuncia y rebeldía.

En el "Coloquio" la crítica aflora por doquier. Todos los personajes pasan por ella en uno $u$ otro grado. En una visión global, puede decirse que del jifero se critica la rudeza y falta de principios; su consideración es de kave de rapiña carnicera". A los pastores se achaca rusticidad y engaño; eran los «lobos», de modo que «despedazaban el ganado los mismos que le habían de guardarn. Del mercader se critica únicamente la ostentación y ambición que manifiesta a través de sus hijos. Sus criados negros, sin embargo, destacan por su mezquindaz, insolencia, latrocinio y deshonestidad. El alguacil reúne en su persona un nutrido elenco de «cualidades", tales como la corrupción, el amancebamiento, la codicia desmedida, el soborno por parte de los delincuentes, la falsa valentía, etc... Los alguaciles, en conjunto, son karrojados, insolentes", "malcriados", "rateros" y, en fin, «jueces y abogados cuando quieren".

El atambor y los soldados de la compañía son krufianes churrulleros"; Cervantes critica en ellos la codicia y la pereza: es gente "vagamuda, inúti(l) y sin provechow. La vieja hechicera Cañizares, a semejanza de sus predecesoras y amigas, la Camacha y la Montiela, es objeto de una crítica feroz. En ella coinciden numerosos defectos, que pueden resumirse en la hipocresía. Es la santidad fingida: urezo poco, y en público - confiesa-; murmuro mucho, y en secreto; vame mejor con ser hipócrita que con ser

${ }^{63}$ Ibidem, pp. 319 y 321, respectivamente. 
pecadora declarada: las apariencias de mis buenas obras presentes van borrando en la memoria de los que me conocen las malas obras pasadas" ${ }^{64}$.

A los gitanos se les critica como colectivo. Son para Cervantes «mala gente». Se caracterizan, como ya se ha visto, por sus «malicias", kembustes", y los «hurtos en que se ejercitan». Tampoco escapa a la crítica su forma de vida: la endogamia, la holgazanería, etc... Una fobia similar se aprecia respecto de los moriscos, a quienes tilda de "víboras", denunciando su mezquindad y avaricia, su fertilidad multiplicadora y su conversión fingida.

El personaje mejor parado parece ser el poeta. Cervantes lo trata con compasión. Sólo critica en él su falta de talento literario y su incapacidad para reconocerlo. De los comediantes critica ksu ociosidad, su ignorancia y su agudeza». El alquimista, el poeta, el matemático y el arbitrista que aparecen en el hospital de Valladolid consituyen un grupo homogéneo: son los representantes del disparate, la locura, la irrealidad. Son aquellos cuyas mentes, absorbidas por sus propios pensamientos, se han apartado de la realidad del mundo. También puede rastrearse la compasión hacia la desgracia de estas personas, que se propone con un fin ejemplarizante.

La crítica irradia a todos los personajes y no solamente a los principales. Veamos sólo dos ejemplos. Los agentes del Estado están corrompidos. El proyecto del arbitrista para el remedio de la hacienda del reino debería realizarse a través de las parroquias, «sin costa de comisarios, que destruyen la repúblicaw. Muy dura es también la crítica a los falsos eruditos, especialmente a los que alardean de dominar el latín: khay algunos romancistas que en las conversaciones disparan de cuando en cuando algún latín breve y compendioso, dando a entender a los que no lo entienden que son grandes latinos, y apenas saben declinar un nombre ni conjugar un verbow. Estas personas andan kengañando al mundo con el oropel de sus gregüescos rotos y sus latines falsos" ${ }^{65}$.

La palabra no es sólo vehículo para la crítica. También lo es para la rebeldía, actitud palpable en algunos pasajes del «Coloquio».

A menudo se constata la impotencia de actuar frente a la injusticia o la inmoralidad. Por ejemplo, Berganza abandona el trabajo en la compañía de comerciantes en vista de la brutalidad de que era objeto: kcansóme aquel ejercicio, no por ser trabajo, sino porque veía en él cosas que juntamente pedían enmienda y

64 Ibidem, p. 340.

65 Las críticas dirigidas a los comisarios aparecen en la p. 357; las dirigidas a los falsos eruditos, en pp. 318 y 321. 
castigo; y como a mí estaba más el sentillo que el remediallo, acordé de no verlow. En otra ocasión, al intentar dar un consejo al Corregidor de Valladolid, actuando de buena fe, "alcé la voz, pensando que tenía habla, y en lugar de pronunciar razones concertadas ladrén, lo que le valió algunos golpes, de los que aún conservaba las "reliquias». En el fondo de esta impotencia subyace una causa de tipo social. La jerarquización social impone actitudes de prudencia en los estamentos más débiles. Así, «nunca el consejo del pobre, por bueno que sea, fue admitido, ni el pobre humilde ha de tener presumpción de aconsejar a los grandes $\mathrm{y}$ a los que piensan que se lo saben todo" ${ }^{66}$.

A lo largo de la novela, los perros Cipión y Berganza se convierten en la voz de la verdad y del sentido común, que resaltan por contraste durante el relato de la azarosa vida de Berganza. Sin embargo, a menudo la realidad se impone y su condición animal no le permite expresar con diafanidad la verdad. En muchos momentos esa "verdad" aparece encadenada. Con los pastores exclama, irritado, Berganza: «No había lobos; menguaba el rebaño; quisiera yo descubrillo; hallábame mudo». En la casa del mercader sevillano logró terminar con las dádivas de la negra, atacándola y, «aunque me quitaron el comer -explica-, no me pudieron quitar el ladrar». Tampoco en esta ocasión friunfó la verdad, pues desistió del intento al ver que había de costarle la vida. Igual sucede con el alguacil, aunque con más éxito. Azuzado por el Asistente para que arremetiese contra el ladrón que huía, Berganza, "cansado de las maldades" de su amo y ante la sorpresa de todos, le atacó. Entonces el Asistente comprendió la burla (el alguacil era el auténtico ladrón) y exclamó: «No lo toque nadie, que el perro hizo lo que yo le mandé" ${ }^{67}$. Esto lo salvó de una paliza segura.

Esto muestra que no siempre está encadenada la verdad. En un pasaje del "Coloquio" la denuncia y rebeldía alcanza su culmen. Se trata de la intención de la huéspeda de la posada sevillana en el asunto del bretón y el alguacil. Es ella quien denuncia la verdad del cohecho exclamando: "Señor alguacil y señor escribano no conmigo tretas, que entreveo toda costuran, «bien conozco a la señora Colindres y sé que ha muchos meses que es su cobertor el señor alguacil" ${ }^{68}$. Sin embargo, la denuncia del débil, como los consejos del pobre, no son atendidos. Aunque la huéspeda les leyó "la historia de sus vidas", lo cierto es que acabó en la cárcel y hubo de pagar diez escudos para salir libre.

66 Ibidem, p. 358.

${ }^{67}$ Ibidem, pp. 311, 323 y 332.

68 Ibidem, p. 325. 
La actitud de denuncia alcanza una dimensión peculiar cuando pone en evidencia situaciones de injusticia, y más concretamente un castigo injusto. De éstos es víctima Berganza muy a menudo, como también es frecuente en tales casos la situación de impotencia al no poder reaccionar contra esa injusticia manifiesta. ¿Cuál es la causa? La falta de habla, la ausencia de palabra. Con ello, Cervantes reivindica una vez más la capacidad denunciadora, a veces demoledora, de la palabra. La expresión y el dominio de la lengua, la cultura en última instancia, tan escasamente extendida en la España del Antiguo Régimen, se revelan como medio eficaz en la denuncia de la injusticia y en la lucha contra la opresión de los poderosos ${ }^{69}$. Veamos algunos ejemplos de estos castigos injustos.

La burla de una moza y el respeto a su hermosura ("por no poner mi boca jifera y sucia en aquellas manos limpias y blancas") casi le cuestan la vida a Berganza, cuyo amo, Nicolás el Romo, le tiró una puñalada, que, "a no desviarme, nunca tú oyeras ahora este cuentom. El perro entonces huye. Con los pastores se encuentra a menudo "castigado sin culpa", pues cada vez que aparece una oveja muerta, el señor del ganado manda castigar a los perros por perezosos y llovían los palos sobre ellos. Este es el pago que recibían los justos por la maldad de los pastores-lobos. El perro decide nuevamente cambiar de oficio, buscando otro en que "por hacer bien, ya que no fuese remunerado, no fuese castigado".

En casa del mercader sevillano conoce Berganza la miel del premio y la amargura del castigo. Satisfecho el mercader por su "buen servicio», ordenó que se le tratase bien y se le diese "ración de pan y los huesos que se levantasen o arrojasen de su mesa, con las sobras de la cocina" y aún más, que lo desatasen para que andase suelto de día y de noche. Además, se le permitió ir al estudio de los jesuitas, acompañando a los hijos del mercader. Pero todo lo perdió a causa de la llamada «razón de estado", de forma que volvió a "entregar el cuello a la cadena y el cuerpo a una esterilla" y a la "ración perruna y a los huesos", que incluso le diezmaban, por estar sujeto, dos gatos romanos. La situación empeoró más, viéndose Berganza víctima de una nueva injusticia. La negra, con la que mantiene "batallas a la sorda" por denunciar la verdad, le alzó la ración de huesos de manera que los suyos "poco a poco iban señalando los nudos

69 En cuanto a la Sevilla del siglo XVII, el pueblo, analfabeto en un 70 por 100 , sólo tendría acceso a una cultura integrada por la literatura oral o por las lecturas en grupo (A. DOMfnguez ORTIZ, Historia de Sevilla. La Sevilla del siglo XVI. Sevilla, 1984, p. 264). 
del espinazow. Incluso un día le trajo una esponja frita con manteca, que a quien la come, se «le hincha el estómago y no sale dél sin llevarse tras sí la vidaw. Era el momento de escapar y cambiar de amo.

La fuga se repite cuando los corchetes que acompañan a su amo el alguacil, después de haber desenmascarado Berganza, en el pasaje antes mencionado, la verdad sobre su amo en presencia del Asistente, quisieron «castigarme, y aun matarme a palos». Sólo la mano providencial de la autoridad municipal lo libró de una muerte segura. En el patio del hospital de Montilla Berganza sufre un nuevo castigo. Esta vez es víctima de la superstición, ignorancia y crueldad de las gentes. Guiado por el miedo, antes que por otra intención alguna, desenmascara a la vieja hechicera, quien califica al perro de "maligno espíritu", siendo considerado por los presentes como kalgún demonio de los que tienen ojeriza continua con los buenos cristianos" ${ }^{70}$. Cayeron sobre él voces, exorcismos y agua bendita, mientras que otros kacudieron a tres o cuatro garrotes, con los cuales comenzaron a santiguarme los lomosw. Un molimiento fue lo que sacó en claro Berganza de esta aventura.

El trato que recibe en la compañía de comerciantes pone en evidencia la ignorancia y crueldad de aquellos. Del mismo modo que intentaron mantear al poeta por la pésima calidad de la comedia, «los entremeses solían acabar por la mayor parte a palos». Para colmo, pusieron a Berganza un «frenow en las representaciones, con lo que quedaba indefenso. «En un entremés -relatame dieron una herida que me llegó casi al fin de la vida». Era nuevamente el momento indicado para marcharse. Por último, cuando Berganza intenta aconsejar al Corregidor de Valladolid sobre el remedio a la prostitución de mozas vagabundas, su condición animal no le permite más que ladrar, hasta conseguir que «me echasen de la sala a palos». Entonces, un lacayo kasió de una cantimplora de cobre que la vino a la mano, y diómela tal en mis costillas, que hasta agora guardo las reliquias de aquellos golpes" "1.

${ }^{70}$ Este pasaje del "Coloquio" puede inscribirse dentro de una de las visiones de la vida desarrolladas en las Novelas Ejemplares de Cervantes y que aparece especialmente en $₫$ Rinconete y Cortadillow: el sentido demoníaco de la vida (CASAldUERO, Op. cit., p. 20).

71 Todos estos castigos y las subsiguientes fugas de Berganza pueden encontrarse en las pp. 305, 310-311, 313,317, 323, 331-332, 345, 354 y 358 de la edición utilizada. Si la prosa del "Coloquio" constituye un movimiento torrencial, en que el tiempo oprime a la vida (toda la realidad de la vida), la fuga es el hilo conductor de los episodios de la obra (CASALDUERO, op. cit., pp. 238-242). 
Unas veces por su buena intención y el deseo de desvelar la verdad, otras por la ignorancia y el desprecio de los hombres, lo cierto es que los palos caen sobre Berganza, el castigo recae sobre el justo y sobre el débil. En cualquier caso, el tema de la indefensión ante hechos injustos, estado en el que el propio Cervantes se vio más de una vez a lo largo de su vida, conduce hasta el terreno de la sátira política. No hay mecanismos de enfrentarse a estas situaciones en el marco de un Estado poderoso y una administración (especialmente la de justicia) corrompida. La conclusión denota profunda amargura, pues se trata de una lucha desigual. Por ello, la solución es siempre la misma: la evasión, pues siempre estaba en el débil, en este caso el perro Berganza, «más el sentillo que el remediallow. Ante la injusticia, impotencia; ante el castigo, evasión, por puro instinto de supervivencia.

\section{COMPORTAMIENTOS RELIGIOSOS. FE Y SALVACIÓN}

La sociedad española, retratada por Cervantes, es una sociedad eminentemente religiosa. La religión, que todo lo impregna durante la Edad Moderna, determina en las personas distintos tipos de comportamientos religiosos ${ }^{72}$.

En primer lugar, hay que mencionar a aquellos que, en virtud de su vocación religiosa, hacen un servicio de extraordinario valor a la comunidad. Aquí lo religioso y lo cotidiano se unen, determinando una forma de vida que se califica de usanta*. Así explica Berganza cómo al ver a Cipión kuna noche llevar la linterna con el buen cristiano Mahudes, te consideré contento y justa y santamente ocupadow. "Trabajar y servir a Dios» es, en el pensamiento de Cervantes, la más digna aspiración del género humano: "para entrar a servir a Dios -explica Cipión-, el más pobre es el más rico; el más humilde, de mejor linaje; y con sólo que se

72 «En la vida religiosa puede darse la posición desinteresada del mundo, como una forma elevada a la que llegan éstos (los misticos)...; pero tampoco se deja de admitir la posición vuelta hacia el mundo, de varias manerasw. En última instancia, esto refleja que, mientras que la religión es una, su práctica puede ser múltiple, entendiendo por rreligiosidadx, ala facultad de practicar una religión, dentro de las limitaciones individuales y sociales" [J. CARO BAROJA, Las formes complejas de la vida religiosa (siglos XVI y XVII). Madrid, 1985, pp. 37 y 29, respectivamente). 
disponga con limpieza de corazón a querer servirle, luego le manda poner en el libro de sus gajes»" ${ }^{73}$.

Sin embargo, estas personas son minoría, la mayor parte de la sociedad la componen los laicos, cuya religiosidad adquiere formas variadas, que se manifiestan a través de sus comportamientos y prácticas religiosas. La vieja hechicera hace una enumeración de estas prácticas más frecuentes: ayunar, rezar, andar romerías o dar limosna, acciones que deben encaminarse a una idea de fondo que las anima: "pensar en bien" ${ }^{74}$. Aunque la vieja reconoce el valor de tales prácticas, no hace ninguna de ellas.

La asistencia a misa es una práctica habitual. El alférez Campuzano, protagonista de "El casamiento engañoso", novela que constituye el pórtico o preámbulo del "Coloquio", se encuentra a su amigo el licenciado Peralta, a quien invita a la posada para contarle sus desdichas. Antes de llegar a la posada, "fueron a San Llorente" y "oyeron misa". También en momentos amargos, como cuando conoce la infidelidad de su esposa, relata: "fuime a San Llorente, encomendéme a Nuestra Señora" ${ }^{75}$. El mismo Berganza reconoce que "muchas veces he entrado en las iglesias" ${ }^{76}$. Se trata, pues, de una práctica común: la visita de los templos, bien para orar o para asistir a las celebraciones religiosas.

Por otro lado, también Cervantes se encarga de mostrar las desviaciones del sentimiento religioso, especialmente la superstición, una realidad palpable en la sociedad española de la Edad Moderna. En el "Coloquio" se manifiesta en las reacciones humanas ante la visión de la vieja bruja, desnuda y en trance, en el patio del hospital de Montilla. Tras la intervención de Berganza, nos relata cómo kcreyeron los más que yo debía de ser algún demonio de los que tienen ojeriza continua con los cristianos, y

${ }^{73}$ Cervantes, Coloquio..., p. 311 . En el fondo, puede rastrearse la admiración de Cervantes por los miembros del estamento eclesiástico (siempre que su actitud esté presidida por esa klimpieza de corazón"). Esa simpatía se constata ante las enseñanzas de los jesuitas, la labor sanitaria de los hospitalarios, la caridad de los jerónimos o la redención de cautivos (por ejemplo, en "La española inglesa") de los trinitarios.

74 Ibidem, p. 343. «La vida religiosa ordinaria se reducía al cumplimiento fiel o a la observancia rígida de los mandamientos. Deberes ordinarios e inexcusables eran la asistencia a la Santa Misa, recepción de los Sacramentos, santificación de los días festivos y la práctica del ayuno todos los viernes del añow [L. Pfand, Cultura y costumbres del pueblo español de los siglos XVI y XVII. Barcelona, 1942 (2." ed.), p. 146].

${ }_{75}$ Cervantes, El casamiento engañoso, ed. cit., vol. II, pp. 283 y 290.

76 Cervantes, Coloquio..., p. 348. Se ha dicho que la iglesia era el centro de la vida española. "Altos y bajos, hombres y mujeres eran asiduos frecuentadores de templos, conventos, santuarios y demás lugares devotos" (J. Delerto Y PINUELA, La vida religiosa española bajo el cuarto Felipe. Madrid, 1952, p. 15). 
unos acudieron a echarme agua benditan, kotros - como se señaló anteriormente- daban voces que me conjurasen", y aun otros, "que no sabían de exorcismos, acudieron a tres o cuatro garrotes, con los cuales comenzaron a santiguarme los lomos" $"$. La reacción popular ante hechos como éste consistió en proclamar que era «demonio en figura de perro».

La religiosidad, en síntesis, nos muestra comportamientos religiosos diversos, como distintos son también los grupos de la sociedad. En algunos casos puede observarse cierta generalización en el relato cervantino. Por ejemplo, al caballero, como ya se indicó, se le presupone entre sus virtudes la piedad religiosa. Nobleza de espíritu y rectitud de obras son cualidades tradicionalmente unidas al linaje. "Buen caballero y gran cristiano" es el capitán del ejército, como también lo son el marqués de Priego y el corregidor de Valladolid.

Por otro lado, existen ciertos grupos cuyos comportamientos religiosos se tienen por inexistentes. Uno de ellos lo constituyen los gitanos. Ya se ha indicado como Berganza no recordaba haber visto jamás a una gitana comulgando en la iglesia. El otro grupo es el morisco. En este caso, la actitud religiosa alcanza una relevancia mayor. No se trata de un simple incumplimiento de las prácticas externas de piedad, ni tan siquiera de la presencia de comportamientos manifiestamente inmorales (aunque «entre ellos no hay castidad"), sino más bien de una cuestión de fondo que debe ser rápidamente atajada: su falsa conversión, pues entre tantos no hay ni tan siquiera uno que crea «derechamentew en la ley cristiana ${ }^{78}$.

${ }^{77}$ Los fenómenos de brujería no son exclusivos de España, sino comunes a toda Europa, alcanzando gran extensión en la primera mitad del siglo XVI. «Toda una literatura demonológica -obra de teólogos- floreció en el siglo XVI, y es ella la que nos da información acerca de las distintas encarnaciones del Ángel de las Tinieblas" (DefourneauX, op. cit., p. 117). Este autor dedica varias páginas a describir las relaciones de los demonios con los humanos, que coinciden con las actividades que relata la hechicera a Berganza. Con gran profundidad aborda Caro Baroja el tema del demonio, tanto en sus aspectos teológicos como en cuanto a su acción cotidiana, los fenómenos de posesión, brujería, etc... (CARo BAROJA, Las formas..., pp. 69-94).

78 Cervantrs, Cologuio..., p. 350. En este sentido, el arzobispo de Valencia, Juan de Ribera, se entregó a la educación cristiana de los moriscos e incluso publicó en 1599 un «Catecismo para instrucción de los nuevamente convertidos de Moros», aunque sin grandes éxitos. Poco después de la expulsión escribe: usiendo baptizados, seguian los moriscos en todo la ley de Mahoma, enseñándola a sus hijos y guardando los ritos del Alcorán públicamente, menospreciando las ceremonias de la santa Iglesia y haziendo irrisión de los Sacramentos, de las imágines y de las cosas sagradas" [en L. CardalllaC, Moriscos y cristianos. Un enfrentamiento polémico (1492-1640). Madrid, 1979, p. 48]. Los testimonios que confirman la opinión de Cervantes son múltiples. 
Distintas formas de religiosidad para los distintos grupos, en una visión claramente generalizada y reduccionista de Cervantes. En cualquier caso, el comportamiento religioso de los individuos remite a dos factores: la fe y la esperanza en la salvación. Son ellos los que alimentan las actitudes piadosas, hasta el punto de que, como ocurre en el caso de la hechicera, si estos principios no animan el comportamiento religioso, de nada aprovecha el aparentarlos. Esta es la base de la crítica de Cervantes hacia la conversión fingida y la hipocresía religiosa.

La fe, confianza, constituye una alta cualidad. Berganza se subleva ante las iniquidades de los pastores y lo hace porque se ha viciado rotundamente el principio de la confianza: «¿Quién será poderoso a dar entender... que la confianza roba?" ${ }^{79}$.

La fe religiosa adquiere un valor más destacable en sociedades que se encuentran sujetas a crisis más o menos cíclicas, en las que hace sus estragos la «mudanza» de los tiempos. En última instancia, si ocurren desgracias es porque el hombre es pecador; la culpa es del hombre y Dios solamente las permite: «todas las desgracias - dice la vieja de Montilla - que vienen a las gentes, a los reinos, a las ciudades y a los pueblos; las muertes repentinas, los naufragios, las caídas, en fin, todos los males que llaman de daño, vienen de la mano del Altísimo y de su voluntad permitente; y los daños y males que llaman de culpa, vienen y se causan por nosotros mismos. Dios es impecable, de donde se infiere que nosotros somos autores del pecado, formándole en la intención, en la palabra y en la obra, todo permitiéndolo Dios, por nuestros pecados" ${ }^{80}$.

Situaciones catastróficas son frecuentes en la España de los siglos XVI y XVII Los cambios de situación y de fortuna van muy unidos a ellas. "Si supieses - dice Berganza - cuán dura cosa es sufrir el pasar de un estado felice a un desdichadow. El resultado final es que usi no acaba la vida es por atormentarla más viviendow. La fugacidad de las cosas y la mudanza de los estados se manifiestan en la urueda variable de la fortunaw. En el fondo subyace la concepción trascendente del «destinow, principio imprevisible e inexorable.

79 Cervantre, Cologuio..., p. 311.

80 Ibidem, p. 317. La fe constituye, por otro lado, «el único refugio ante la adversidad y de ella se espera la conservación de la salud, la modificación de la meteorologia, el remedio contra el hambre, la buena marcha de la economía, la victoria sobre el enemigo y el control de las fuerzas ocultas de la aún mal conocida naturalezan (F. AgUIuR PITA, Historia de Sevilla. Siglo XVIII. Sevilla, 1982, p. 298). 
Este movimiento continuo destaca más en una sociedad que se tiene por estable. «Los que ayer estaban en la cumbre de la rueda de la fortuna -explica Cipión-, hoy están hollados y abatidos a los pies de la desgracia y tenidos en poco de aquellos que más los estimaban». La fortuna depara a muchos la desgracia, como a aquellos "cuerdos" locos del Hospital de la Resurrección de Valladolid (el alquimista, el poeta, el matemático y el arbitrista). Aún más, kal desdichado las desdichas le buscan y le hallan" ${ }^{81}$. Son éstas expresiones del escepticismo de la sociedad y del pesimismo del escritor.

En este estado de ánimo encuentra amplia resonancia el fenómeno del pecado. La vieja hechicera sabe filosofar sobre esta realidad, a la vez que reconoce los "muchos" que ella ha cometido. Si apartarse del pecado es difícil, para la vieja resulta imposible. Confiesa haberlo intentado (whe hecho yo mis diligencias: heme acogido a ser hospitalera; curo a los pobresw), pero reconoce que sus buenas obras son fingidas. Se tiene, como ya se ha indicado, por "hipócrita", pues intenta silenciar sus malas obras con la apariencia de otras buenas. Esta es la forma de comportamiento religioso que denuncia Cervantes: la apariencia, el fingimiento, la hipocresía, la «santidad fingida». Es la denuncia de una realidad amarga: las prácticas vacías, la apariencia sin contenido, la ausencia de fe auténtica. Este es el consejo que da la vieja a Berganza: «que seas bueno en todo cuanto pudieres; y si has de ser malo, procura no parecerlo en todo cuanto pudieres" ${ }^{82}$.

Es la realidad dual bien-mal, Dios-demonio. La vieja reconoce la sujeción al demonio que significa la mentira, la confusión, la falta de verdad, incluso la ignorancia, ya que «nunca a lo que le preguntamos responde a derechas, sino con razones torcidas y de muchos sentidos. Así, que a este nuestro amo y señor no hay que preguntarle nada, porque con una verdad mezcla mil mentiras; y a lo que yo he colegido de sus respuestas, él no sabe nada de lo por venir ciertamente, sino por conjeturasw. Por el contrario, Dios se manifiesta como perdón y bondad. «Está más prompto - reconoce la vieja - a perdonar pecados que a permitirlos». En última instancia, su problema es estrictamente de fe y de voluntad, pues es incapaz de apartarse del mal, aunque «con todo esto - dice- sé que Dios es bueno y misericordioso y que El sabe lo que ha de ser de mí, y basta" ${ }^{83}$.

81 Cervantrs, Coloquio..., pp. 346 y 320, respectivamente.

22 Ibidem, p. 340.

83 Ibidem, pp. 339, 342 y 343. 


\section{CONCLUSIONES}

A través del análisis histórico del "Coloquio de los perros» de Cervantes podemos esbozar las siguientes conclusiones.

En primer lugar, la literatura, al igual que el arte, constituye una fuente imprescindible para la historia de la sociedad. No debe olvidarse nunca que la ficción novelada nace siempre de la realidad existente, aunque no se limita a reflejarla. Por ello, somos conscientes de la inevitable limitación que la obra literaria presenta en su uso como fuente histórica. Sin embargo, estableciendo una gradación, la utilidad es mayor en las obras que se inscriben en una línea marcadamente realista, como ocurre con el "Coloquiow. Esta obra, como muchas otras, nos sirve efectivamente para comprobar la crisis mental del hombre del siglo XVII.

La nota distintiva más clara de la sociedad española consiste en la presencia de un sistema de castas, que determina la agrupación de la población en los grupos de cristianos viejos y cristianos nuevos (conversos). Junto a esto, debe destacarse la existencia de esclavitud, especialmente en el suroeste español, fenómeno en el que influye la reafirmación del derecho romano y la prosperidad comercial, evidenciando unas prácticas que si no tienen reconocimiento legal, al menos son toleradas.

En general, los personajes del "Coloquio" pertenecen al tercer estado o estado llano. Este estamento, base de la sociedad y de la economía, se presenta como una realidad compleja y muy variada. No constituye una masa amorfa ni homogénea, sino que se compone de individuos con distintas ocupaciones, motivaciones y aspiraciones. Paradójicamente es el restado» menos conocido y el menos tratado por el historiador, en parte por la dificultad de encontrar unas fuentes adecuadas. En este campo, la literatura es una fuente privilegiada para conocer cómo vivían, qué hacían y qué sentían los hombres del siglo XVII.

En la consideración de los nobles, Cervantes prima los valores de la nobleza tradicional (linaje, valor...). El protagonismo nobiliario del siglo XVII español no parece reforzar la unidad de este estamento, sino más bien su disgregación, a la vez que el fortalecimiento de la Corona. Por otro lado, el mercader que aparece en la novela no representa a lo más significativo de la burguesía. No hay en él una conciencia de burgués ni un orgullo de clase. No se encuentra completamente satisfecho de su posición social. El dinero, que sustenta esa posición, es un medio por el que aspira al ennoblecimiento de sus hijos, en contraste con la austeridad en su vida personal. 
Entre los personajes más destacados se encuentran los soldados, individuos de baja extracción social, que hacen compatible su oficio militar con las más diversas actividades: los títeres, el juego, etc... Es decir, su ocupación real es la ociosidad; son vagabundos, hombres en quienes el espíritu aventurero o noble de la guerra brilla por su ausencia. En otro género de actividad el poeta aparece retratado como un desdichado que vive en la miseria auténtica.

Los grupos negros, gitano y morisco comparten la animadversión de Cervantes y de un sector mayoritario de la sociedad de la época. Los negros se encuentran en la marginidad por constituir un grupo carente de «libertad personal» y también por sus costumbres reprobables, es decir, por la falta de cualidades personales. Los gitanos constituyen una lacra social y la causa de su marginación puede rastrearse en su fuerte espíritu de clan y en sus actividades delictivas, tratándose de una marginación étnica y social. Los moriscos, por último, se encuentran marginados en virtud de la casta. Los perjuicios que causan a la colectividad son de índole económica (atesoran fortunas apartándolas de la circulación), religiosa (su conversión es fingida) y social (endogamia y proliferación).

La vida es un principio sujeto a una contrastable relatividad. De gran importancia para Cervantes, carece de toda consideración entre las gentes de los bajos fondos por él retratadas. Este nulo valor puede tener un origen instintivo (jifero) o moral (hechicera). La razón, por otra parte, prerrogativa humana por excelencia, debe ser, según el escritor, un principio orientador del mundo, un criterio para discernir. Si importante es la razón singular, más lo es en comunicación con las demás. El hombre es un ser eminentemente social y ello queda de manifiesto con el uso de la forma dialogada, pues la comunicación siempre enriquece al ser humano. La palabra, además de deleitar y entretener, puede estar al servicio de la virtud y entonces constituye un arma noble, o al servicio de la maldad (murmuración) y entonces es un arma cruel y aún mortífera. Sin embargo, su uso es muy positivo como vehículo de crítica, denuncia y rebeldía.

Las instituciones, fruto de la racionalidad humana, son de vital importancia para el funcionamiento de la vida social. Sin embargo, su corrupción es contemplada por Cervantes con especial acritud, hasta el punto de agudizar en este punto su crítica y pesimismo. Ello se debe a que, en el fondo, el incumplimiento de la ley devalúa la razón humana. Abundando en este tema, Cervantes refleja una sociedad en que la verdad se encuentra a menudo encadenada y el humilde se ve impotente para modificar 
la situación existente. A esta impotencia contribuyen diversos factores, como el escaso nivel cultural del conjunto de la población en el siglo XVII, la primacía de una filosofía de la «fuerza», etc...

La religiosidad de los personajes del "Coloquion es de signo ritual, basada en una exteriorización que refleja el interior del hombre. En este sentido, como en otros, la época barroca es eminentemente sintética. En ella lo racional y espiritual se difunde a través de los sentidos. Ahora bien, también Cervantes critica la apariencia vacia de contenido, el parecer que no responde al ser, la mera exteriorización de prácticas religiosas o su falseamiento intencionado. El caso, muy particular, de la vieja hechicera es el prototipo de la hipocresía más cruel y de la falta de voluntad. Por otra parte, se manifiesta en la novela la relación entre situaciones catastróficas y el pecado del género humano, muy extendida durante la Edad Moderna, lo que evidencia un sentimiento de desconfianza en las posibilidades del ser humano.

De todo ello se infiere la importancia de la literatura como cauce idóneo, eso sí contrastado con otro tipo de fuentes, que nos conduce a un análisis profundo de las motivaciones y de los comportamientos humanos. Técnicas y corrientes como la historia cuantitativa y serial, por poner un ejemplo, no pasan de ser en el campo de la mentalidad un auxiliar de trabajo, en parte porque no constituyen un medio adecuado para analizar magnitudes difícilmente cuantificables. La obra literaria, contrastada, asume, pues, un papel primordial o privilegiado.

María ANTONia Bel BRavo MIGUEL LUIS LÓPEZ MUÑ̃Z 